\title{
Groundwater Resources of the Devils Postpile National Monument-Current Conditions and Future Vulnerabilities
}

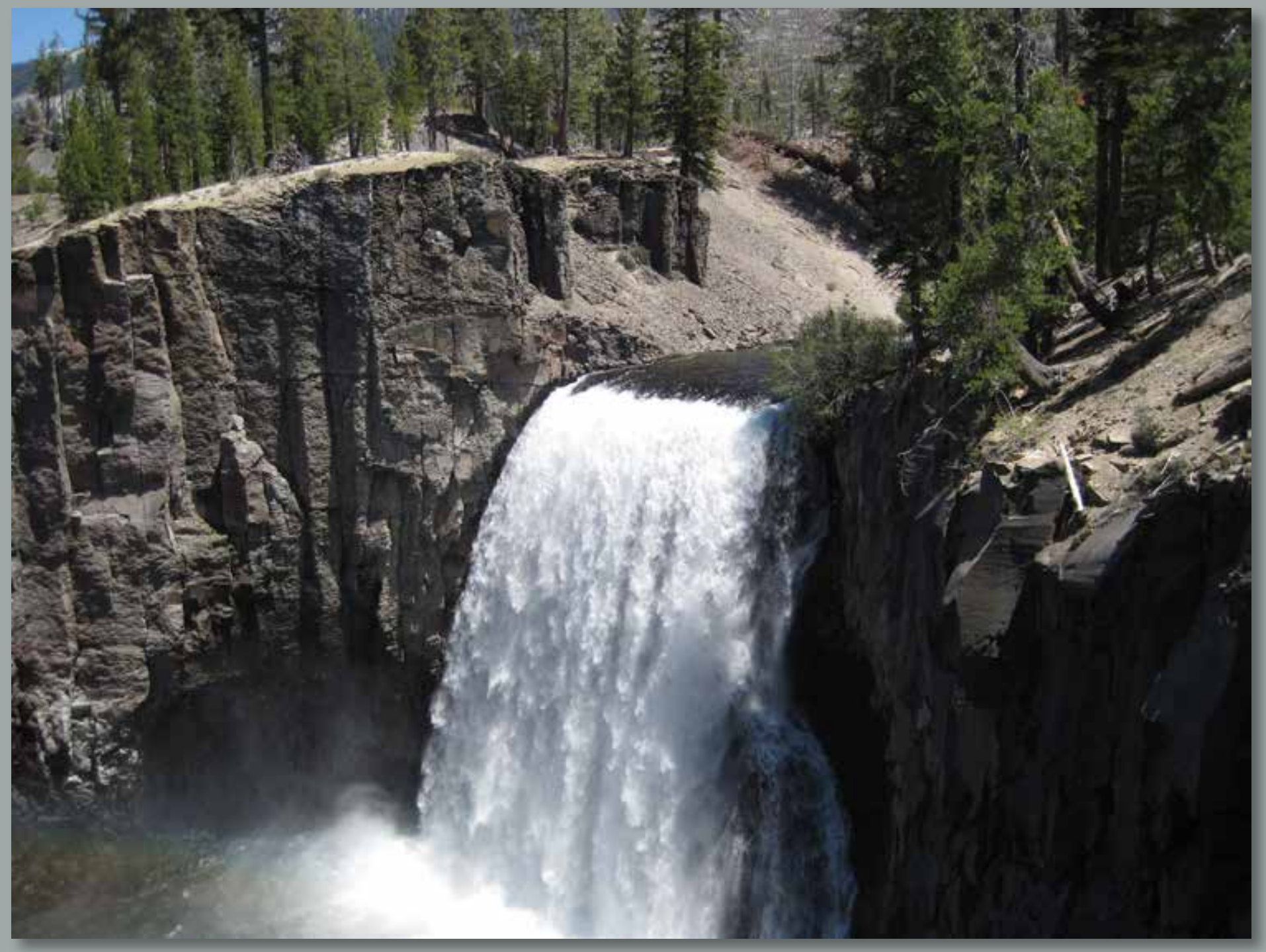

Scientific Investigations Report 2017-5048 
Cover. Middle Fork of the San Joaquin River flowing over Rainbow Falls in May 2013. Photograph by William C. Evans, USGS. 


\section{Groundwater Resources of the Devils Postpile National Monument-Current Conditions and Future Vulnerabilities}

By William C. Evans and Deborah Bergfeld

Scientific Investigations Report 2017-5048 


\title{
U.S. Department of the Interior \\ RYAN K. ZINKE, Secretary
}

\section{U.S. Geological Survey William H. Werkheiser, Acting Director}

\author{
U.S. Geological Survey, Reston, Virginia: 2017
}

For more information on the USGS - the Federal source for science about the Earth, its natural and living resources, natural hazards, and the environment—visit http://www.usgs.gov or call 1-888-ASK-USGS (1-888-275-8747).

For an overview of USGS information products, including maps, imagery, and publications, visit http://store.usgs.gov.

Any use of trade, firm, or product names is for descriptive purposes only and does not imply endorsement by the U.S. Government.

Although this information product, for the most part, is in the public domain, it also may contain copyrighted materials as noted in the text. Permission to reproduce copyrighted items must be secured from the copyright owner.

Suggested citation:

Evans, W.C., and Bergfeld, D., 2017, Groundwater resources of the Devils Postpile National Monument-Current conditions and future vulnerabilities: U.S. Geological Survey Scientific Investigations Report 2017-5048, 31 p., https://doi.org/10.3133/sir20175048.

ISSN 2328-0328 (online) 


\section{Acknowledgments}

We thank Deanna Dulen, Superintendent of the Devils Postpile National Monument, for proposing this study, securing funding, and continuing to encourage the work over its duration. Monica Buhler aided in the sample collection and compiled the water data collected by monument staff as part of their existing protocol. Other monument staffers who assisted with the field work include Catherine Fong, Jon Winters, and Andrew Osborne. Ed Furlong (U.S.

Geological Survey) was extremely helpful in the study of emerging contaminants. Mark Huebner (U.S. Geological Survey) contributed high-quality anion analyses. Bill Erb and Clifford Mann of the Mammoth Mountain ski area provided information on salt use. John Pedersen (Mammoth Community Water District) and Jason Olin (Los Angeles Department of Water and Power) contributed data on water usage, snow accumulation, and annual precipitation. Casey Shannon (U.S. Forest Service) provided information on water use in local campgrounds. Careful reviews by Jennifer Lewicki and Monica Buhler greatly improved the manuscript.

\section{Contents}

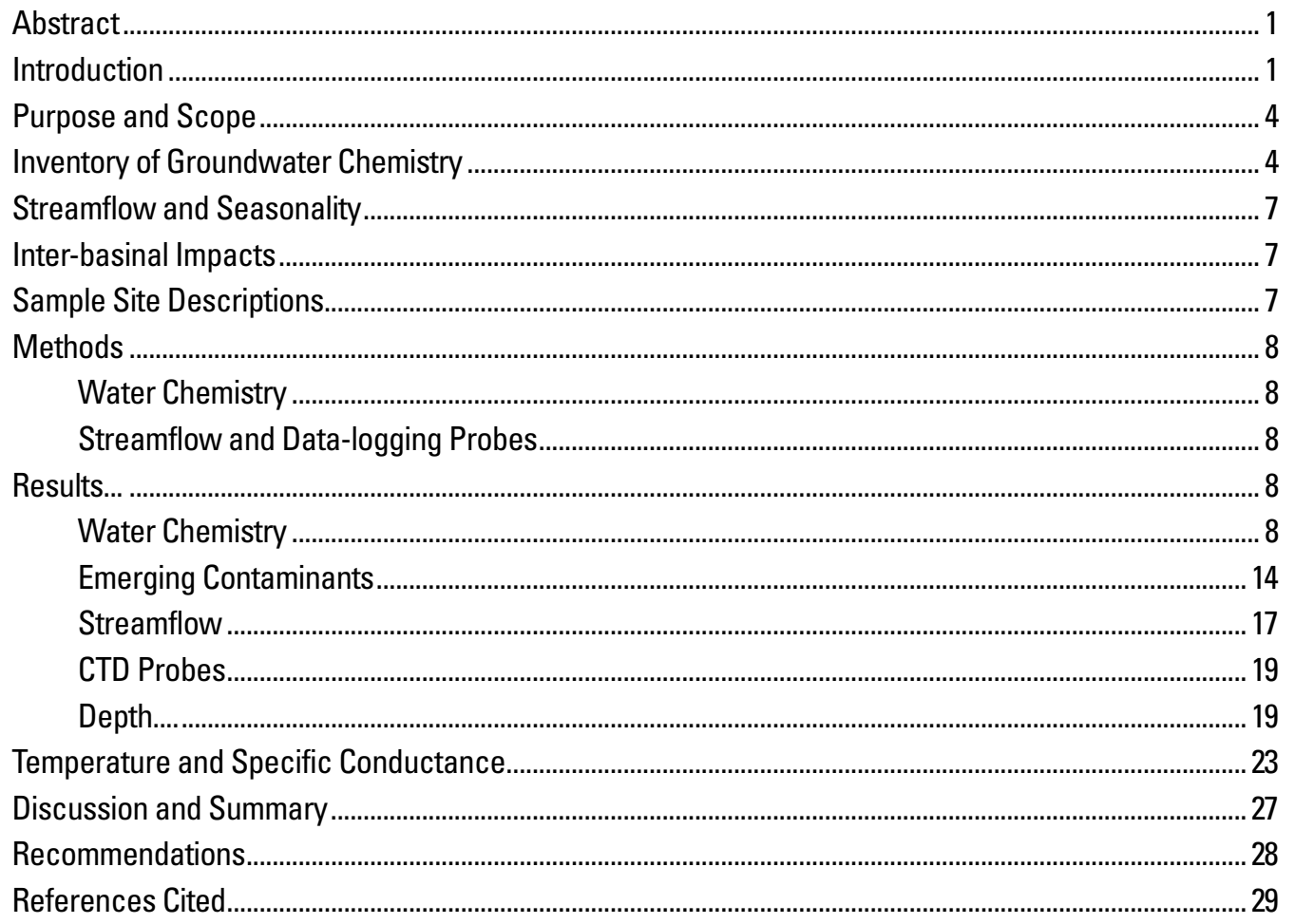




\section{Figures}

1. Geologic map of the Devils Postpile area and the Middle Fork of the San Joaquin River, which flows from north to south..

2. Topographic map of the study area with sample locations........................................................ 4

3. Graph showing major-ion chemistry and drainage rock-type at selected sites......................... 9

4. Graph of major-ion chemistry at selected sites on various dates during this study compared with data from samples collected in the late 1990s.

5. Graph of major-ion chemistry at stream monitoring sites compared with that at their main source springs during summer 2013.

6. Graphs of concentrations of dissolved species at the five monitoring sites over the course of the study

7. Graphs of variations over time at the monument supply well.

8. Graphs of the concentrations of several species versus chloride in the monument supply well, upper Dry Creek, soda springs, thermal springs, the San Joaquin River, and all other groundwater samples in table 2

9. Graphs of stable isotope composition of sampled water

10. Graph of the isotopic composition of dissolved inorganic carbon for five samples obtained in this study.

11. Graph showing gaged streamflows at the five monitoring sites..

12. Graph showing gaged streamflows at sites $L R C, R L O$, and $L B C$, and the monthly mean discharge of the Middle Fork of the San Joaquin River at the monument.

13. Graph of long-term records of April 1 snow water equivalent at Mammoth Pass and Minarets 2 and the combined annual mean river discharge by water year at three sites within 100 kilometers of the monument...

14. Graphs comparing water depth above the conductivity-temperature-depth probe at each of the five monitoring sites as recorded by the probe transducer and as derived from the measured distance between the water surface and reference point.

15. Graphs comparing water depth above the conductivity-temperature-depth probe, as derived from the measured distance between the water surface and reference point, and gaged streamflow at the five monitoring sites.

16. Graphs of stream depths measured by the conductivity-temperature-depth probes and daily precipitation at Doe Ridge.

17. Graphs of temperature and specific conductance for the period from September 1, 2012, to December 1, 2015, from the conductivity-temperature-depth probes and from hand-held meters used during site visits.

18. Graphs showing expanded record of temperature and depth from the conductivitytemperature-depth probe at site RLO and hourly precipitation at Doe Ridge.

19. Graph of expanded record from the conductivity-temperature-depth probe at site RLO and daily precipitation at Doe Ridge showing lack of correlation between conspicuous spikes in specific conductance and precipitation, temperature, or depth 


\section{Tables}

1. Sample site numbers, codes, descriptions, and locations.

2. Chemical data for springs, streams, and a water supply well sampled during this study [this table is available in Excel file format online only at https://doi.org/10.3133/sir20175048]

3. Dissolved inorganic carbon and the Henry's Law pressure of dissolved $\mathrm{CO}_{2}$ calculated from field

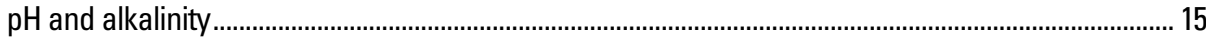

4. Emerging contaminants reported for each site ....................................................................... 15

5. Emerging contaminant compounds and their detection limits................................................. 16

6. Gaged streamflow at the five monitoring sites ........................................................................ 18 



\title{
Groundwater Resources of the Devils Postpile National Monument-Current Conditions and Future Vulnerabilities
}

\author{
By William C. Evans and Deborah Bergfeld
}

\section{Abstract}

This study presents an extensive database on groundwater conditions in and around Devils Postpile National Monument. The database contains chemical analyses of springs and the monument water-supply well, including major-ion chemistry, trace element chemistry, and the first information on a list of organic compounds known as emerging contaminants. Diurnal, seasonal, and annual variations in groundwater discharge and chemistry are evaluated from data collected at five main monitoring sites, where streams carry the aggregate flow from entire groups of springs. These springs drain the Mammoth Mountain area and, during the fall months, contribute a significant fraction of the San Joaquin River flow within the monument. The period of this study, from fall 2012 to fall 2015, includes some of the driest years on record, though the seasonal variability observed in 2013 might have been near normal. The spring-fed streams generally flowed at rates well below those observed during a sequence of wet years in the late 1990s. However, persistence of flow and reasonably stable water chemistry through the recent dry years are indicative of a sizeable groundwater system that should provide a reliable resource during similar droughts in the future. Only a few emerging contaminants were detected at trace levels below 1 microgram per liter $(\mu \mathrm{g} / \mathrm{L})$, suggesting that local human visitation is not degrading groundwater quality. No indication of salt from the ski area on the north side of Mammoth Mountain could be found in any of the groundwaters. Chemical data instead show that natural mineral water, such as that discharged from local soda springs, is the main source of anomalous chloride in the monument supply well and in the San Joaquin River. The results of the study are used to develop a set of recommendations for future monitoring to enable detection of deleterious impacts to groundwater quality and quantity.

\section{Introduction}

Devils Postpile National Monument was created in 1911 mainly to protect a spectacular outcrop of columnar lava as well as an impressive waterfall over outcrops of other lava flows (Johnson, 2013). However, encompassing these two features within the long, narrow monument boundaries led to inclusion of a sizeable reach of the Middle Fork of the San Joaquin River, which flows into the north end of the monument and, with only a short excursion into surrounding U.S. Forest Service (USFS) lands, leaves the monument at its southern end. Thus from an environmental perspective, the monument is as much a hydrologic preserve focused around the river and its several tributary streams as it is a geologic wonder.

Another important geologic aspect (fig. 1) is that the monument forms somewhat of a boundary between exposures of granitic rocks to the west and volcanic rocks to the east (Hildreth and others, 2014). This setting has a major impact on local hydrology and water chemistry. Volcanic rocks are inherently more permeable than granite, leading to more infiltration of rain and snowmelt and less direct runoff. The volcanic rocks in this region are also much younger than the granitic bedrock and contain an abundance of minerals that are reactive in groundwater, especially in this case, as the groundwater is enriched in magmatic $\mathrm{CO}_{2}$ (Cook and others, 2001; Evans and others, 2002). Thus the area east of the monument is a substantial source of groundwater and dissolved solids.

Snowmelt and storm runoff are certainly important water sources in the high-elevation headwaters of the San Joaquin River, but the tributary streams that join the river within and around the monument are mostly spring fed. Some of the smaller streams go dry during the summer months, but thanks to strong perennial spring discharge, several streams provide year-round aquatic habitat. In areas lacking forest cover, for example, as a result of fires and blowdown, the streams form conspicuous green ribbons of lush vegetation, shrubs, and herbaceous plants. Fish occupy some of the lower reaches.

Other hydrologic features of note (figs. 1,2) include Sotcher Lake, $\sim 1$ kilometer $(\mathrm{km})$ east of the monument boundary, and wetland areas where diffuse seepage of groundwater is visible. Sotcher Lake, with a surface area of $0.1 \mathrm{~km}^{2}$, is a large catchment for the water discharge from numerous springs located upslope to the north and east, and thus has perennial inflow and outflow. The outflow stream drains into Reds Creek, which reaches the San Joaquin River inside the monument boundary. One sizeable wetland within the monument is in a meadow adjacent to the administrative area and ranger station, at a sweeping bend in the river. Seeps occur on both sides of the river, but visible seepage is highly seasonal. The Reds Meadow area just east of the monument includes several zones of diffuse seepage, some perennial, all of which eventually feed into Reds Creek. Another wetland with perennial seepage occurs near the Pumice Flat area at the edge of the river, about $1.5 \mathrm{~km}$ upstream from the monument. 


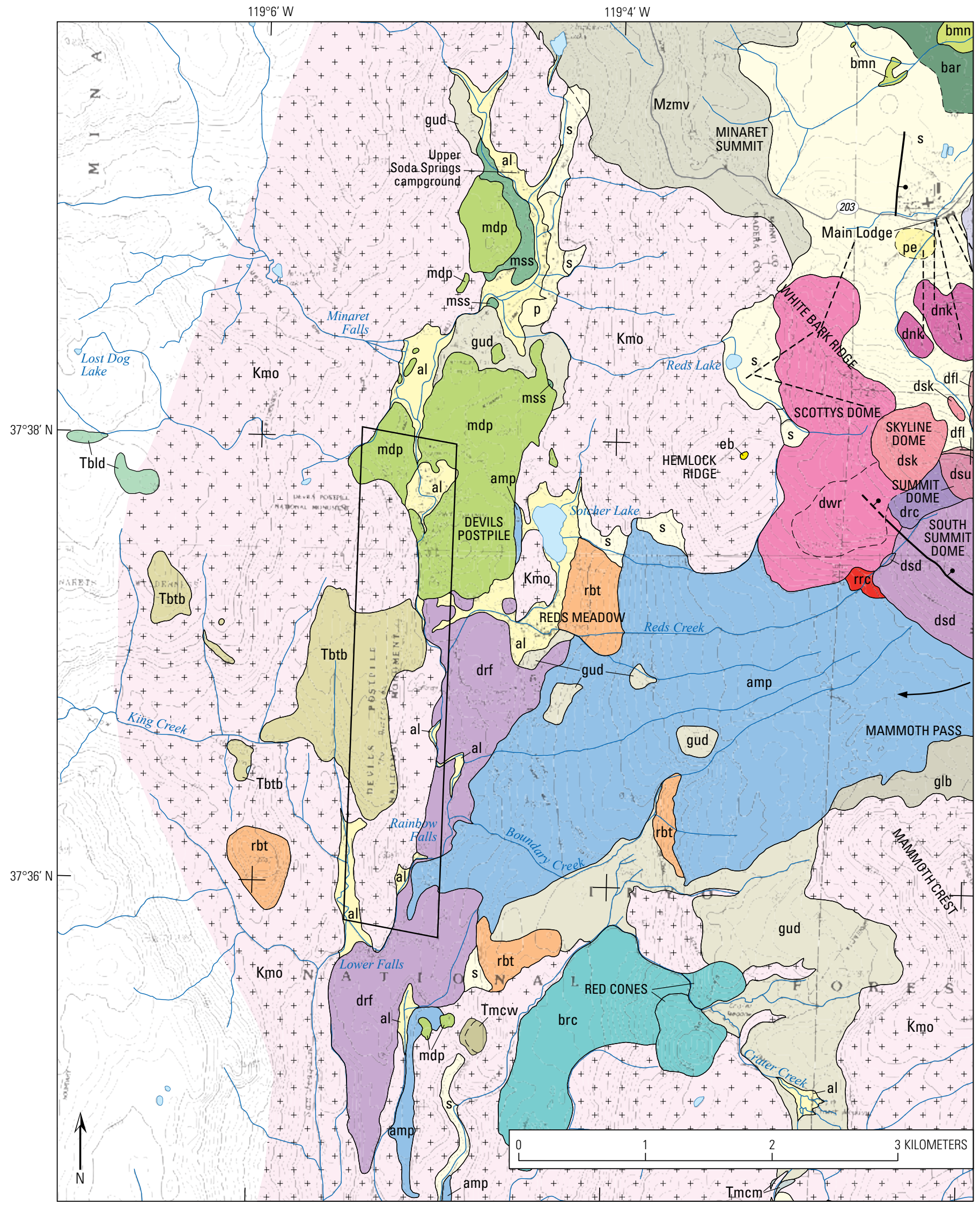

Figure 1. Geologic map of the Devils Postpile area and the Middle Fork of the San Joaquin River, which flows from north to south (modified from Hildreth and Fierstein, 2016). For complete descriptions of geologic units, see Hildreth and Fierstein (2016). 


\section{EXPLANATION}
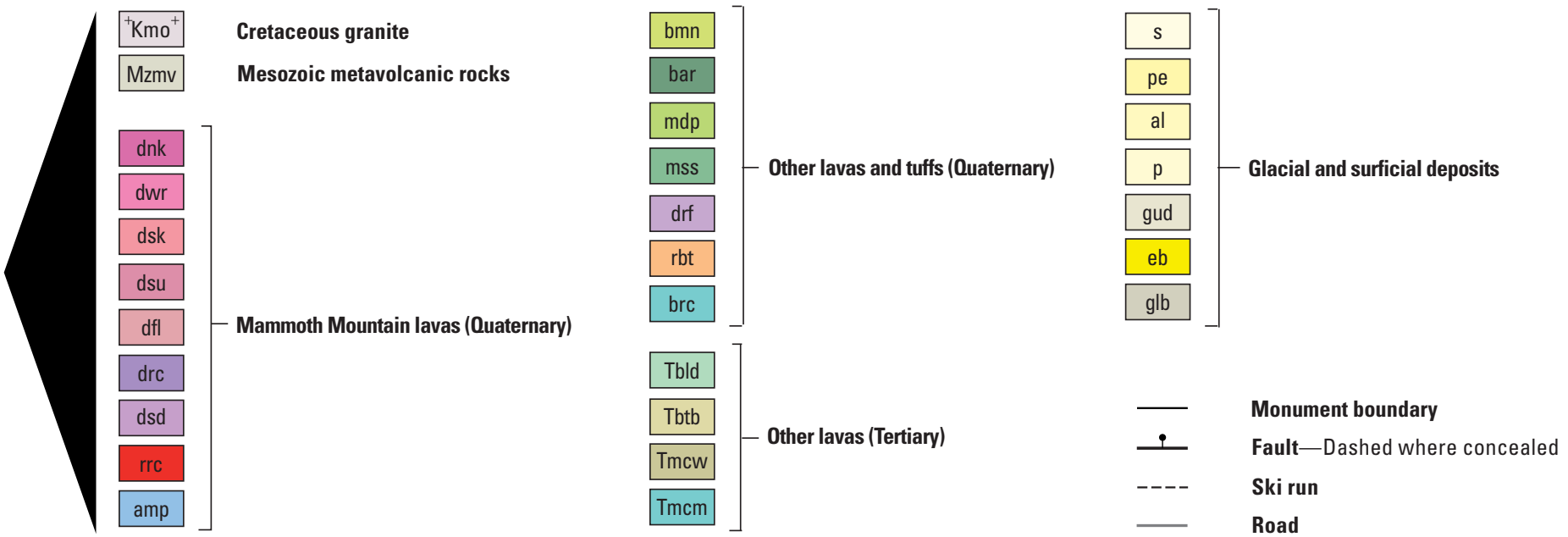

Several thermal and mineral springs occur in the region. A $45^{\circ} \mathrm{C}$ hot spring provides water for an old bathhouse in Reds Meadow. The spring, long known as Reds Meadow Tub (Sorey and others, 1991), is one of two similar hot springs enclosed in concrete tubs some tens of meters apart. Warm water seeps from various places on the hillside north of Reds Meadow Tub, and water discharging from several springs about $0.5 \mathrm{~km}$ to the north is slightly thermal at $19^{\circ} \mathrm{C}$. The water from all of these thermal features flows into the monument and the San Joaquin River by way of Reds Creek.

Mineral springs are so called because their dissolved mineral content is conspicuously higher than that of normal groundwater. The mineral springs in this region are carbonated and are known as soda springs. They are easily recognized by the iron staining around the spring vents. The most vigorous soda spring is located at the edge of the San Joaquin River by the footbridge about 200 meters (m) downstream from the monument ranger station. Although the main spring vent is often submerged during high river discharge, the spring flows perennially and can easily be spotted within the river as a result of the copious discharge of gas bubbles. The soda spring at Upper Soda Springs Campground, $\sim 2.5 \mathrm{~km}$ upstream from the monument boundary, consists of a closely spaced pair of vents that occasionally discharge to the river, but seasonally shrink to stagnant pools and eventually go dry. Gas bubbles appear in the springs when water is present. During the course of our study, we located a small and previously unstudied soda spring at the river's edge near the confluence with Boundary Creek, just outside of the monument's east edge. Several soda springs in the region around the monument were popular sources of drinking water a century ago among the early visitors (Waring, 1915).
Although the mountainous region surrounding the monument receives heavy winter snowfall, groundwater is a critical resource in the area due in part to the paucity of water reservoirs and the generally dry summertime conditions. The monument relies on a supply well (Richard P. Arber and Associates, 2007) near the headquarters area to meet the daily needs $\left(10-20 \mathrm{~m}^{3}\right)$ of the on-site staff and visitors during the open season (June-October). Numerous popular USFS campgrounds adjacent to the monument use groundwater pumped from the alluvial aquifer at Pumice Flat. A private supply well serves the resort and pack station at the southern end of Reds Meadow. The Mammoth Mountain ski area (MMSA) uses groundwater from wells about $5 \mathrm{~km}$ east of the monument, and the Mammoth Community Water District (MCWD) pumps groundwater from wells about $10 \mathrm{~km}$ east of the monument for public supply to the Town of Mammoth Lakes, at the eastern base of Mammoth Mountain. The multiple and increasing needs for groundwater in this region raise concerns about future availability. In addition, high public visitation rates to the monument and surrounding USFS lands in the summer, and to the ski area/mountain bike center year-round, raise the risk that contaminants derived from people and their vehicles could degrade groundwater quality.

Groundwater serves important ecological needs as well; for example, in supporting the biota associated with perennial streams and in the wetland habitats mentioned above. The quantity and quality of groundwater within the monument is a concern to monument managers. Because of this concern, the U.S. Geological Survey (USGS) was asked to help develop a plan to monitor and protect this resource. To better understand the resource and potential human impacts, the study area was broadened into lands adjacent to the monument to include 


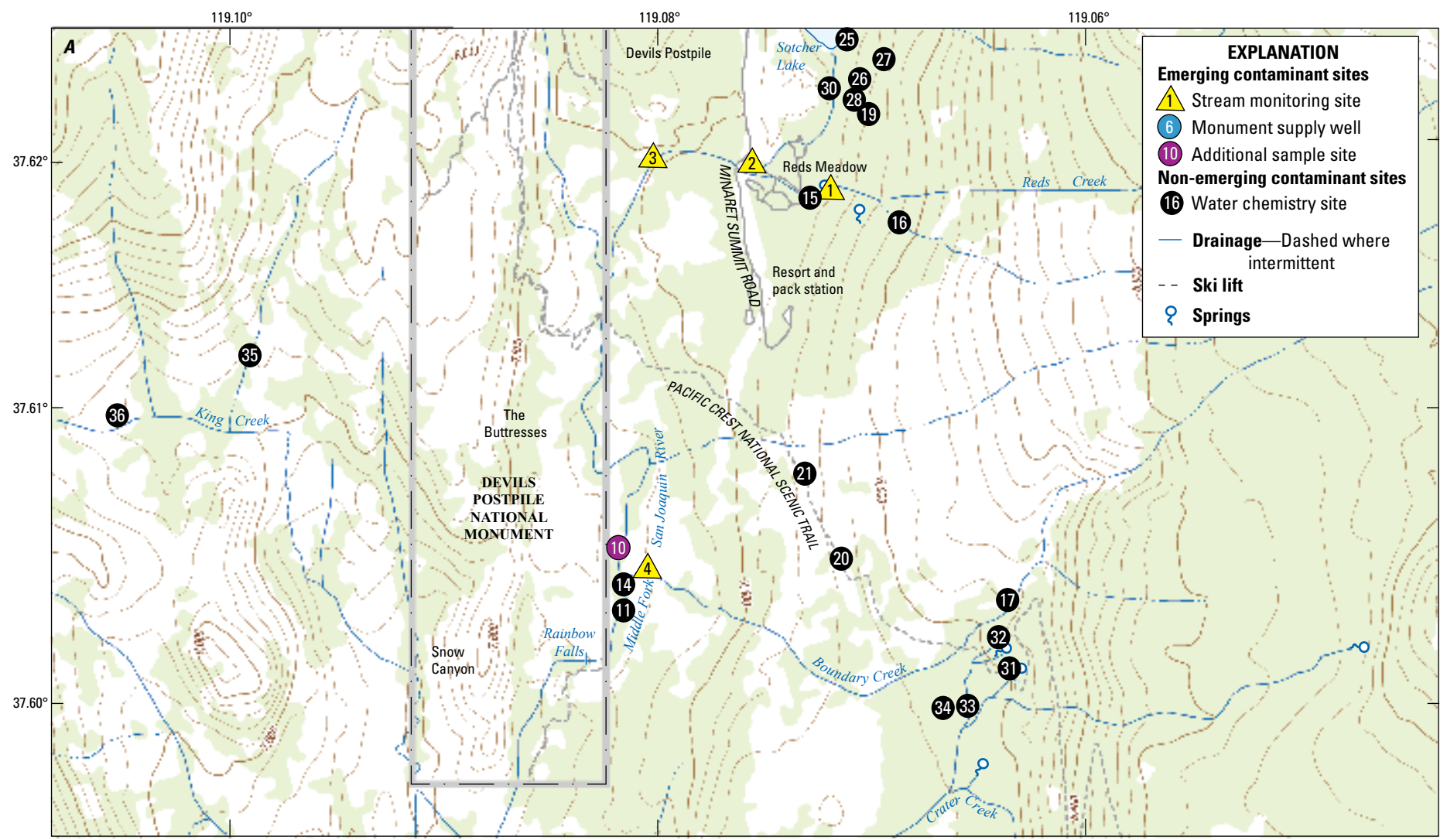

Figure 2. Topographic map of the study area with sample locations: $(A)$ southern part, $(B)$ northern part. Site descriptions are in table 1. Sites 1-5 are the spring-fed creeks monitored over the duration of the study (yellow triangles); site 6 is the monument supply well (blue circle); sites 7-10 and 12 are additional locations analyzed for emerging contaminants (purple circles). Sampling sites not analyzed for emerging contaminants are marked as black circles. Sites 5, 18, 22, and 23 drain the granitic rocks of Hemlock Ridge; sites 35 and 36 drain granitic rocks west of the monument; sites 12 and 29 mainly drain Tertiary volcanic rocks (Bailey, 1989) that overlie the Mesozoic metavolcanic rocks at the top edge of figure 1. Other sites drain exposures of Quaternary volcanic rocks except for the San Joaquin River, which drains numerous rock types.

groundwater influx to the San Joaquin River upstream of the monument's south boundary, either through direct spring discharge or in spring-fed streams.

\section{Purpose and Scope}

The purpose of this study was to develop a monitoring program for the supply and quality of groundwater in Devils Postpile National Monument and field test the program over a period of three years (water years 2013-2015). The monitoring program is intended to become a standard tool by which the monument can recognize significant changes in its groundwater resources in future years under conditions that might include a changing climate, increased regional development and groundwater usage, and (or) catastrophic events such as forest fires. The study consisted of several parts: reconnaissance sampling of numerous springs and streams within and around the monument boundaries; establishment of five monitoring points on the major spring-fed streams draining into the section of the
San Joaquin River that traverses the monument; and repetitive sampling of the main supply well within the monument. A unique feature of the study was a search for emerging contaminants, a set of organic tracer compounds mostly reflecting human activity. Low-level detection of these compounds has only recently become possible, and this study provides an important first look at their abundance and distribution.

\section{Inventory of Groundwater Chemistry}

The locations of numerous springs in and around the monument were known from previous studies (for example, Sorey and others, 1998; Evans and others, 2002; Burak, 2010), and chemical analyses were available for many springs. Existing data suggested that spring chemistry was reasonably stable from year to year. Nevertheless, we decided to conduct a new survey of spring chemistry in order to fill in gaps, check for long-term changes, and to have chemical data collected concurrently with stream discharge measurements. Sample sites 


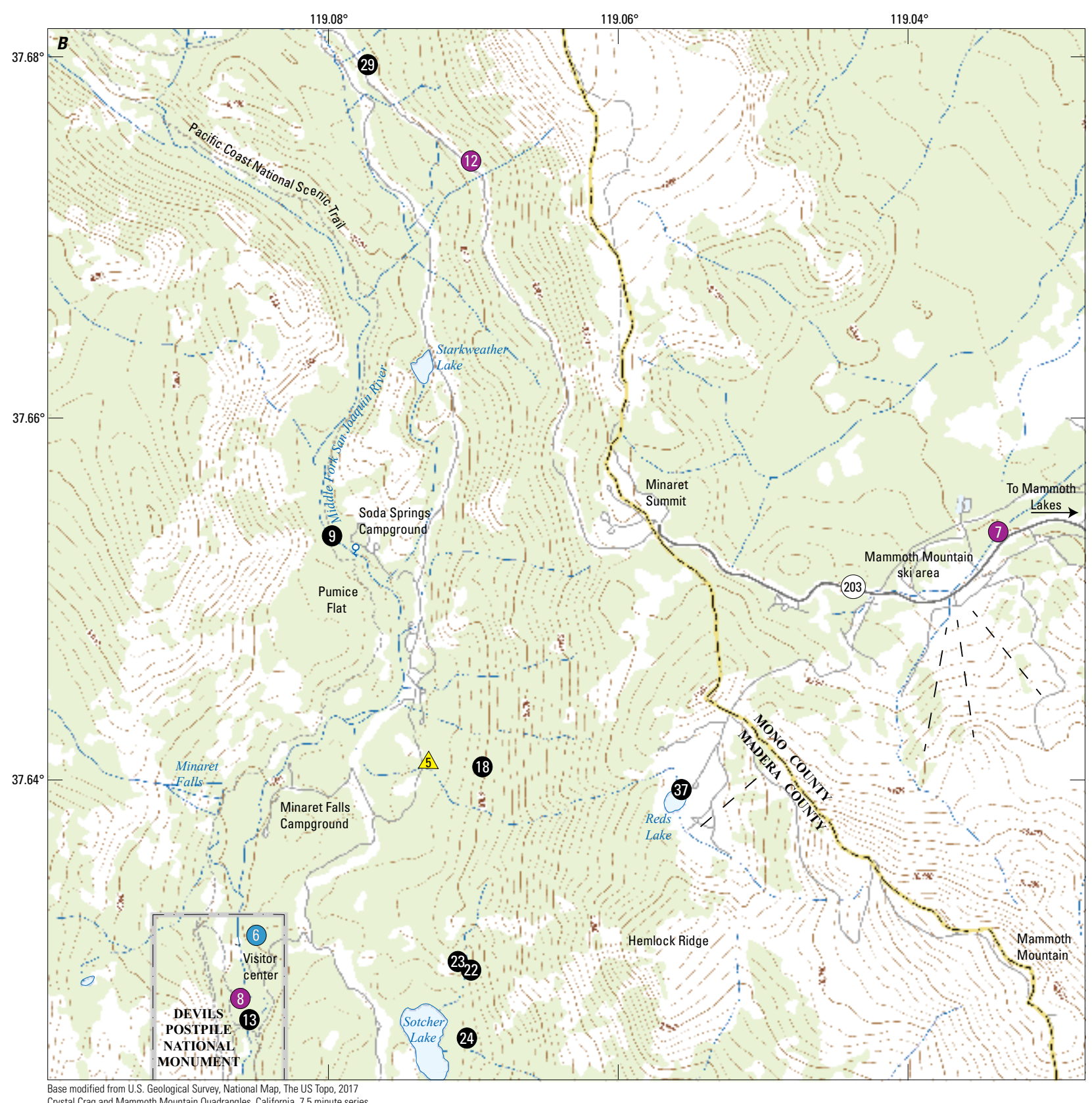

are listed in table 1 and shown in figure 2. Site codes are also given in table 1, many of which were carried over from previous studies by USGS groups (Sorey and others, 1998; Evans and others, 2002; U.S. Geological Survey, 2002). Brief descriptions in table 1 distinguish springs from creeks, wells, and so forth, and together with location coordinates, should provide enough detail to allow the sites to be identified by future workers.

In addition to sampling for basic chemistry, water was collected for isotopic analysis of hydrogen and oxygen. These isotopes show variations across the broad region encompassing the monument and have been used to infer the location of precipitation that recharges the groundwater system at various points (White and others, 1990; Sorey and others, 1991). Extra emphasis was placed on constraining seasonality at selected sites because a previous report detailed a large seasonal shift in some springs just north of our study area (Burak, 2010).

Our sampling strategy included a focus on emerging contaminants. These are organic compounds which are commonly found in wastewater, can be detected at ultra-low concentrations, and can persist in groundwater long enough to serve as tracers of human-induced contamination (Zaugg and others, 2007). They include industrial and household chemicals as well as substances present in pharmaceuticals, personal care products, beverages, and other products. Examples include DEET (N,N-Diethyl-meta-toluamide), an externally applied insect repellant; caffeine, the stimulant in many beverages 
Table 1. Sample site numbers, codes, descriptions, and locations (NAD83). Elevations from handheld global positioning system (unsurveyed). [CTD, conductivity-temperature-depth; m, meters; mE, meters Easting; mN, meters Northing]

\begin{tabular}{|c|c|c|c|c|c|}
\hline Site number & Code & Description & $\mathrm{mE}$ & $\mathbf{m N}$ & Elevation (m) \\
\hline 1 & RMC & Stream (at CTD probe) & 317097 & 4165552 & 2,362 \\
\hline 2 & SLO & Stream (at CTD probe) & 316813 & 4165657 & 2,316 \\
\hline 3 & LRC & Stream (at CTD probe) & 316304 & 4165700 & 2,315 \\
\hline 4 & $\mathrm{LBC}$ & Stream (at CTD probe) & 316301 & 4164025 & 2,260 \\
\hline 5 & RLO & Stream (at CTD probe) & 317065 & 4168078 & 2,369 \\
\hline 6 & DPPSW & Monument supply well at well head & 316035 & 4167059 & 2,338 \\
\hline 7 & UDC & Upper Dry Creek & 320405 & 4169245 & 2,697 \\
\hline 8 & SIEN seep & Seep near monitor well & 315879 & 4166639 & 2,306 \\
\hline 9 & SJRUP & San Joaquin River above monument & 316531 & 4169419 & 2,376 \\
\hline 10 & SJRM & San Joaquin River above Boundary Creek & 316166 & 4164068 & 2,260 \\
\hline 11 & LSJR & San Joaquin River below Boundary Creek & 316201 & 4163907 & 2,254 \\
\hline 12 & RMRS & Spring on Road below Minaret Summit & 317359 & 4171689 & 2,575 \\
\hline 13 & DPP Soda & Soda spring at bridge & 315928 & 4166552 & 2,322 \\
\hline 14 & BCSS & Soda spring below Boundary Creek & 316195 & 4163975 & 2,260 \\
\hline 15 & RMT & Reds Meadow Tub (hot spring) & 317010 & 4165549 & 2,333 \\
\hline 16 & RMCS & Headwater spring on Reds Creek & 317396 & 4165382 & 2,445 \\
\hline 17 & LBCU & Headwater spring on Boundary Creek & 317732 & 4163858 & 2,448 \\
\hline 18 & RLOS & Headwater spring Below Reds Lake & 317334 & 4168042 & 2,435 \\
\hline 19 & SLS & Sotcher Lake warm spring & 317245 & 4165895 & 2,382 \\
\hline 20 & PC1 & Creek at Pacific Crest Trail & 317054 & 4164073 & 2,397 \\
\hline 21 & $\mathrm{PC} 2$ & Creek at Pacific Crest Trail & 316949 & 4164350 & 2,375 \\
\hline 22 & SL1 & Spring in granite above Sotcher Lake & 317266 & 4166759 & 2,408 \\
\hline 23 & SL2 & Creek draining granite above Sotcher Lake & 317253 & 4166784 & 2,385 \\
\hline 24 & SL3 & Spring from landslide above Sotcher Lake & 317283 & 4166412 & 2,371 \\
\hline 25 & SL4 & Seep at trail above Sotcher Lake & 317156 & 4166187 & 2,336 \\
\hline 26 & SL5 & Seep above alder thicket near Sotcher Lake & 317191 & 4166060 & 2,382 \\
\hline 27 & SL6 & Spring on old pack trail near Sotcher Lake & 317261 & 4166110 & 2,384 \\
\hline 28 & SL7 & Spring on trail near Sotcher Lake & 317125 & 4165958 & 2,345 \\
\hline 29 & RMR2 & Stream at road near Agnew Meadows & 316764 & 4172269 & 2,554 \\
\hline 30 & SL8 & Sotcher Lake discharge & 317078 & 4165974 & 2,369 \\
\hline 31 & ASS & Spring south of Boundary Creek & 317755 & 4163590 & 2,463 \\
\hline 32 & LBCS & Spring south of Boundary Creek & 317706 & 4163743 & 2,455 \\
\hline 33 & LBCS1 & Stream feeding Crater Creek & 317580 & 4163453 & 2,426 \\
\hline 34 & LBCS2 & Stream feeding Crater Creek & 317496 & 4163476 & 2,421 \\
\hline 35 & $\mathrm{KC} 2$ & Intermittent tributary to King Creek & 314671 & 4164930 & 2,338 \\
\hline 36 & $\mathrm{KC}$ & King Creek & 314180 & 4164704 & 2,336 \\
\hline 37 & RL & Reds Lake & 318592 & 4167866 & 2,830 \\
\hline
\end{tabular}


that are consumed and excreted by visitors; and menthol, a mint extract that is both consumed as a flavoring agent and applied externally as a scent in some skin lotions. Some of the compounds, like menthol, have natural sources and cannot prove a direct link to human activity. Other compounds, like DEET, have no natural sources.

\section{Streamflow and Seasonality}

Many of the streams in the study area are dominantly spring fed, and thus gaging these streams provides an estimate of groundwater discharge. Some stream locations were only gaged once during the course of the study, but at five primary monitoring sites (fig. 2), gaging was repeated in different seasons to constrain streamflow variability during the spring-to-fall months. Concurrently obtained water chemistry can be used to distinguish and quantify groundwater components in the streams as distinct from surface water inflow.

To more fully constrain the annual variability, an In-Situ AquaTroll 200 conductivity-temperature-depth (CTD) probe was deployed at each of the five primary monitoring sites. Information collected and stored by the probes can yield a continuous record of stream characteristics that extends, for example, through major storms or through winter months when site visits are impractical.

\section{Inter-basinal Impacts}

The boundaries of groundwater basins may not correspond exactly to the topographic high points that clearly separate surface water drainage basins. Inter-basinal flow of groundwater, while typically considered a minor factor in groundwater budget calculations, nevertheless occurs and has been quantified in some large groundwater basins of the western United States (for example, Eakin and others, 1976). Inter-basinal flow of groundwater could potentially affect the groundwater resources of the monument due to the proximity of other groundwater users, such as the Mammoth Mountain ski area and to a lesser extent, the Town of Mammoth Lakes. One purpose of this study was to evaluate the likelihood and extent of inter-basinal flow.

The ski area pumps $\sim 5.2 \times 10^{5} \mathrm{~m}^{3}$ of groundwater annually from wells about $5 \mathrm{~km}$ east of the monument (Breibart and others, 2001). One well near Chair 11 in the Minaret Summit area is only $\sim 700 \mathrm{~m}$ east of the drainage divide. The Mammoth Community Water District (MCWD) pumps groundwater from wells about $10 \mathrm{~km}$ east of the monument for public supply to the Town of Mammoth Lakes; amounts vary depending on the supply of surface water but are not to exceed $5 \times 10^{6} \mathrm{~m}^{3}$ annually (Mammoth Community Water District, 2005). If drawdown of groundwater levels related to pumping extends westward into the groundwater basin serving the San Joaquin River, the supply of groundwater to the river (and the monument) would be correspondingly reduced.

Alternatively, inter-basinal groundwater flow could deliver contaminants from human activity east of the drainage divide into the San Joaquin River basin. This is a particular concern with regard to the ski area, which is heavily visited in wintertime, and also hosts mountain biking crowds in summer. A few of the ski runs are located west of the divide, in the Reds Lake area (figs. 1, 2). During the ski season, personal care products such as sunblock and lip balm carried by the skiers are dropped and lost in the snow. The abundance of such products is easily visible on the ski runs just after snow melt and before the runs are cleaned by the ski-area staff, and raises the possibility that chemical compounds from these products (emerging contaminants) could leach into snowmelt and end up in groundwater. The ski area also applies large quantities of salt to the snow surface on some of the runs to improve skiing conditions - about 120,000 pounds in an average winter (Clifford Mann, MMSA, oral commun., 2013). Thus, one focus of our study was the search for emerging contaminants and salt $(\mathrm{NaCl})$ in groundwaters west of the drainage divide.

\section{Sample Site Descriptions}

The five main monitoring sites (1-5) are RMC, SLO, LRC, LBC, and RLO (table 1; fig. 2). These spring-fed streams carry most of the known groundwater discharge that enters the San Joaquin River in the vicinity of the monument. RMC (\#1) is Reds Creek just above the hot spring in Reds Meadow. SLO (\#2) is the combined outflow of Sotcher Lake and a number of springs and seeps immediately south of the lake. SLO and RMC meet in Reds Meadow and this combined stream plus discharge from the hot spring and other seeps is monitored at the Lower Reds Creek (LRC) site (\#3) just above the inflow to the river. The Lower Boundary Creek (LBC) site (\#4) is located just above the confluence with the river. The fifth site, RLO (\#5), is located where the stream below Reds Lake crosses Minaret Summit Road. This site was called Reds Lake Outflow because the USGS topographic map (Mammoth Mountain 7.5 minute quadrangle) shows the stream draining Reds Lake within the Mammoth Mountain ski area. In fact, this stream originates at a spring far down slope from the mapped headwaters, and the same is true for Reds Creek and Boundary Creek. Streamflow above these springs, identified as RLOS (\#18), RMCS (\#16), and LBCU (\#17), respectively, is likely rare based on observations during this and previous studies. The spring discharge points themselves may migrate up or down slope seasonally, but the stream channels above the springs, marked on USGS topographic maps, must carry water only during times of rapid snowmelt.

The five monitoring sites were all sampled eight times between September 2012 and October 2015. Most other sites were sampled once; the monument water supply well DPPSW (\#6) being a notable exception. The record from a downhole CTD probe in this well showed a puzzling annual variation, and as interest in this pattern grew, this well was sampled repeatedly in 2014 and 2015, but without field measurements of temperature, $\mathrm{pH}$, and specific conductance. Another site sampled several times was upper Dry Creek (UDC). Dry Creek 
drains numerous popular ski runs as well as the area around the main ski lodge, and this site (\#7) is located just downslope from this highly visited zone (fig. 2). The UDC site was expected to be the one most influenced by human activity.

The hot spring known as the Reds Meadow tub (RMT; \#15) was popular with hikers prior to the recent closure of the old bath house. The other notable thermal spring in the study area is Sotcher Lake spring (SLS; \#19), a large warm spring that discharges over a conspicuous waterfall into the stream flowing out of Sotcher Lake. The main soda spring (DPPSoda; \#13) and a newly identified soda spring (BCSS; \#14) were both sampled. The soda springs in upper Soda Springs Campground were not flowing during our site visits. A number of other groundwaters (\#20-30) were sampled, including a seep (\#8) near a National Park Service Sierra Nevada Network Inventory and Monitoring (SIEN) well (Nesmith, 2015). The San Joaquin River was sampled at three sites (\#9-11), above the upper Soda Springs Campground (SJRUP), within the monument just above the confluence of Boundary Creek (SJRM), and below both Boundary Creek and the newly identified soda spring (LSJR). Four of the sample sites are in areas with little human visitation and can be considered to represent background water quality for our study. These sites are RMRS (\#12) and RMR2 (\#29), which drain the ridge north of Minaret Summit, and King Creek (KC; \#36) and its tributary (KC2; \#35), which drain granitic rocks west of the monument. Other large springs discharge near the source spring for Boundary Creek (LBCU) and resemble it in terms of chemistry (fig. 2). However, these springs (\#31-32) actually discharge into Crater Creek, which enters the San Joaquin River far downstream from the monument.

\section{Methods}

\section{Water Chemistry}

The location of each sampled feature was determined to within a few meters with a hand-held global positioning system (GPS). Water temperature, specific conductance, and $\mathrm{pH}$ were measured on-site using hand-held meters. The $\mathrm{pH}$ meter was calibrated with buffer solutions at the temperature of the water.

Samples were collected for chemical analysis using standard methods that have been described elsewhere (Bergfeld and others, 2013). Briefly, water was filtered on-site into plastic bottles using a plastic syringe and 0.45 -micrometer $(\mu \mathrm{m})$ filters. The bottle for cation analysis was acidified to $\mathrm{pH} 2$ with ultrapure nitric acid. Glass bottles were filled with unfiltered water for alkalinity determinations and analysis of stable isotopes of hydrogen and oxygen. Samples for emerging contaminants were collected without filtration into pre-cleaned 1-liter amber glass bottles following procedures outlined in Wilde (2002), and were refrigerated or stored on ice between collection and analysis.

Alkalinity samples were titrated at the end of each day of sampling with standardized solutions of $\mathrm{H}_{2} \mathrm{SO}_{4}$. Chemical analyses were conducted at USGS laboratories in Menlo Park, Calif. Anions were analyzed by ion chromatography, cations by argon plasma optical emission spectrometry. Stable isotope analyses were performed by mass spectrometry at the USGS Reston Stable Isotope Laboratory (Revesz and Coplen, 2008a,b).

Emerging contaminants were analyzed at the USGS National Water Quality Laboratory in Denver, Colo. using Schedule 1433, which detects 59 volatile organic compounds (Zaugg and others, 2007). Nine representative sampling sites were chosen for this somewhat costly analysis. All of the monitoring sites, except for SLO, and the groundwater supply well (DPPSW) were chosen. SLO was excluded because LRC captures the flow from that site. The SIEN site was selected to represent seepage in the wetland area near the main visitor center. SJRM was sampled to constrain conditions in the San Joaquin River downstream of most visitation, and RMRS was chosen to represent background. Upper Dry Creek (UDC) was sampled in duplicate because this site was considered representative of runoff from the most highly visited part of the ski area. In addition, two sample bottles were filled in the field with water certified to be free of volatile organic compounds and submitted as field blanks.

\section{Streamflow and Data-logging Probes}

Streamflow was determined using a wading rod and pygmy meter, following standard USGS procedures (Buchanan and Somers, 1969). At the five primary monitoring sites, a nail was driven into a tree or fallen log directly overhanging the water surface to serve as a fixed reference point. The distance from nail to water was measured with a steel tape each time the stream was gaged.

Probes were fixed in position by attachment to a steel pipe driven into the streambed. Onboard data-loggers within the probe housing were set to store values of specific conductance (SC), temperature (T), and depth (D) of water above the pressure sensor at 30-minute intervals. The probes were calibrated at deployment but not subsequently recalibrated. Instead, probe readings were compared to values measured using calibrated handheld meters each time the site was visited.

The CTD probes are housed in a rugged case and have an estimated lifespan of about 5 years, but as installed in mountain streams, face hazards such as moving debris and ice blocks during spring thaw and runoff. Thus obtaining data over a single annual cycle can be a challenge. Another limitation is the depth resolution. Even with the most sensitive pressure sensor available (full scale $=1,000$ centimeters $[\mathrm{cm}] \mathrm{H}_{2} \mathrm{O}$ ), depth changes in the centimeter range have a large uncertainty.

\section{Results}

\section{Water Chemistry}

Table 2 (available online only) gives the water chemistry results correlated to the site numbers shown in figure 2 . The major-ion chemistry of the four background sites and several other sites from this study are shown in figure 3 . The waters of King Creek (KC) and its tributary (KC2) are low in major 


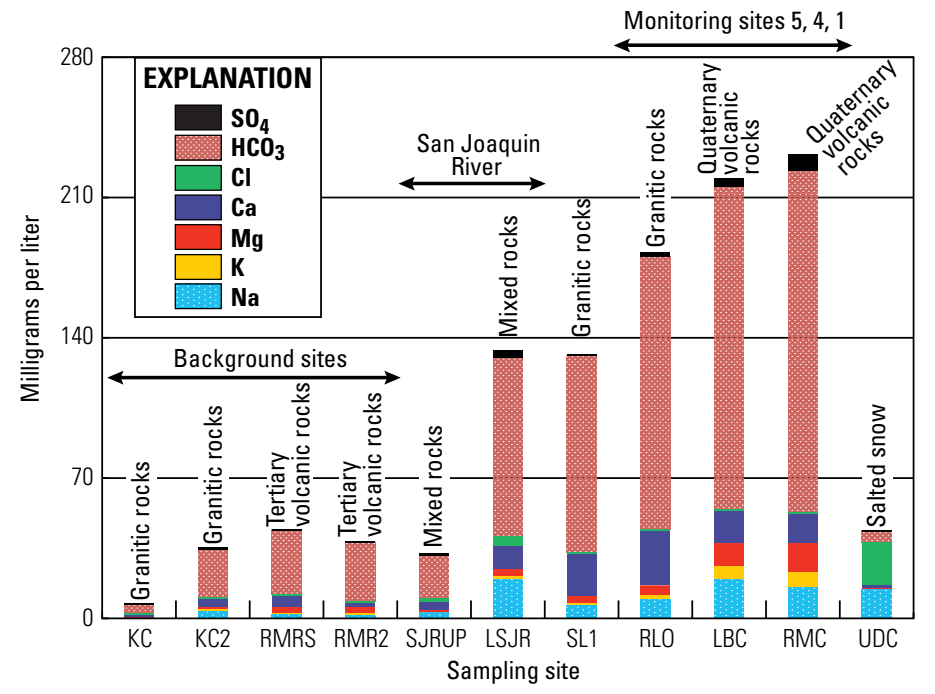

Figure 3. Graph showing major-ion chemistry and drainage rock-type at selected sites. Samples collected on various dates except the San Joaquin River upstream (SJRUP) and downstream (LSJR) samples, which were both collected on October 14, 2015.

ions, representative of water draining granitic rocks. The two sites draining Tertiary volcanic rocks on the ridge north of Minaret Summit (RMRS and RMR2) are only slightly higher in ionic content but show a relative enrichment in magnesium, as expected from dissolution of volcanic source rocks of any age (for example, Feth and others, 1964). In contrast, monitoring sites LBC and RMC, which drain Mammoth Mountain, are much higher in major ions, reflecting the greater reactivity of the young volcanic rocks. Interestingly, monitoring site RLO, which drains from the granitic ridge separating Mammoth Mountain from the San Joaquin River (fig. 1), chemically resembles water reacting with young volcanic rocks. Another spring (SL1) that drains into Sotcher Lake from this granitic ridge also appears to have some interaction with young volcanic rocks, as does the adjacent creek (SL2; table 2). Major-ion chemistry thus suggests that groundwater recharged on Mammoth Mountain penetrates through the granitic ridge to reach these discharge points, a flowpath hypothesized by Burak (2010).

The two San Joaquin River samples shown in figure 3, collected in October 2015, show the large north-to-south change in river chemistry at low-flow conditions. Upstream (SJRUP), the river chemistry resembles that of the four background sites, whereas downstream (LSJR), the impact of groundwater inflow is clear. A representative sample from upper Dry Creek is included to show the effect of salt $(\mathrm{NaCl})$ on this feature, the only water where bicarbonate $\left(\mathrm{HCO}_{3}\right)$ is not the dominant anion.

The chemistry of the large warm spring SLS, which seems to be a diluted version of the hot spring RMT, is shown in figure 4. The two sampled soda springs (BCSS and DPPSoda) are compositionally alike, but DPPSoda was partly inundated by the river during our sampling in August 2013. A sample collected without river inundation in 1999 shows it to be about twice as high in major ions as BCSS, but not quite as high as a 1999 sample of the springs at upper Soda Springs Campground (USC). Soda springs are the only waters in the study area that are naturally rich in chloride, and despite their low discharge, they likely represent

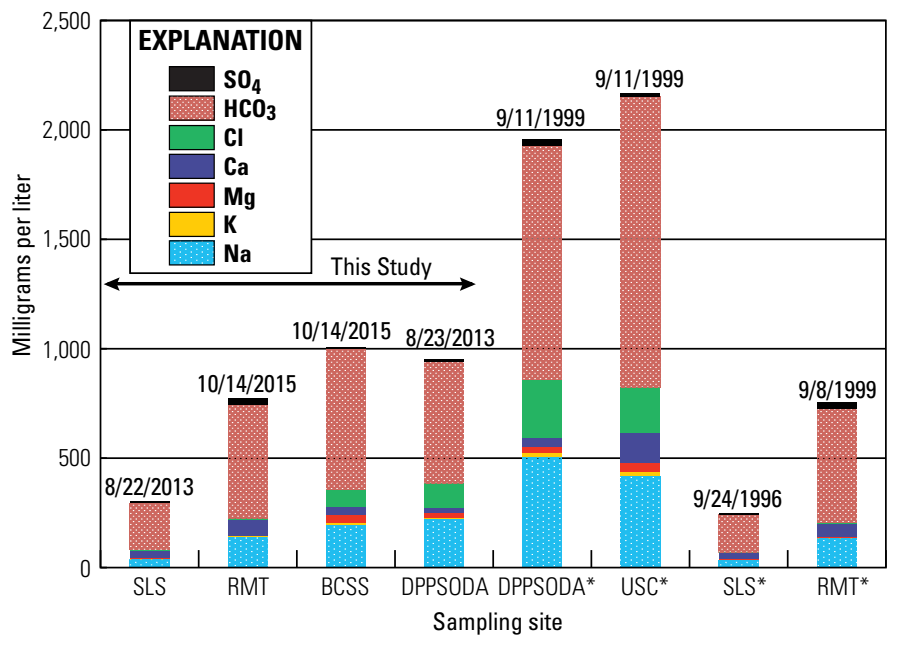

Figure 4. Graph of major-ion chemistry at selected sites on various dates during this study compared with data from samples collected in the late 1990s (U.S. Geological Survey, 2002), denoted with an asterisk.

the main source of chloride to the river. Comparison of chemical data from samples collected during the 1990s suggests that the chemistry of most groundwaters in the study area is reasonably stable over decades; SLS and RMT demonstrate this in figure 4.

Similarities in water chemistry of the monitored streams (RMC, LBC, SLO, RLO) and their upslope source springs (RMCS, LBCU, SLS, RLOS, respectively) show that the streams consist almost entirely of groundwater (fig. 5). The stream at SLO does mix water from the large warm spring SLS with more dilute water from a number of springs that feed into Sotcher Lake (for example, SL1 shown in figure 3 ). Some additional analyses of spring chemistry from the 1990s are included in figure 5, and they differ just slightly from the newer ones. The differences could reflect long-term trends, but seasonal variations must also be considered.

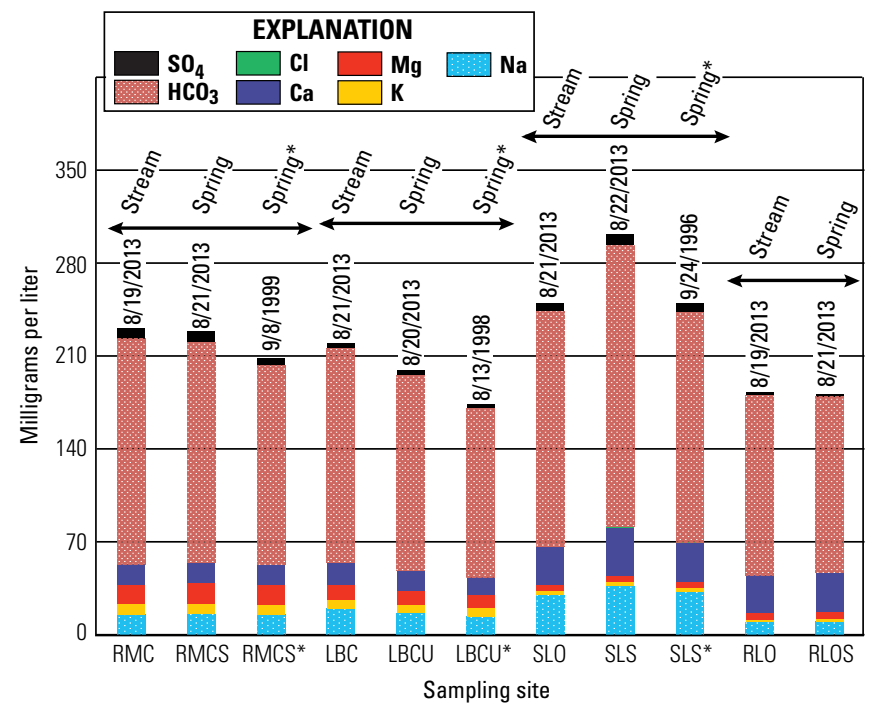

Figure 5. Graph of major-ion chemistry at stream monitoring sites compared with that at their main source springs during summer 2013. Spring chemistry in the late 1990s is also shown where available (U.S. Geological Survey, 2002), denoted with an asterisk. 

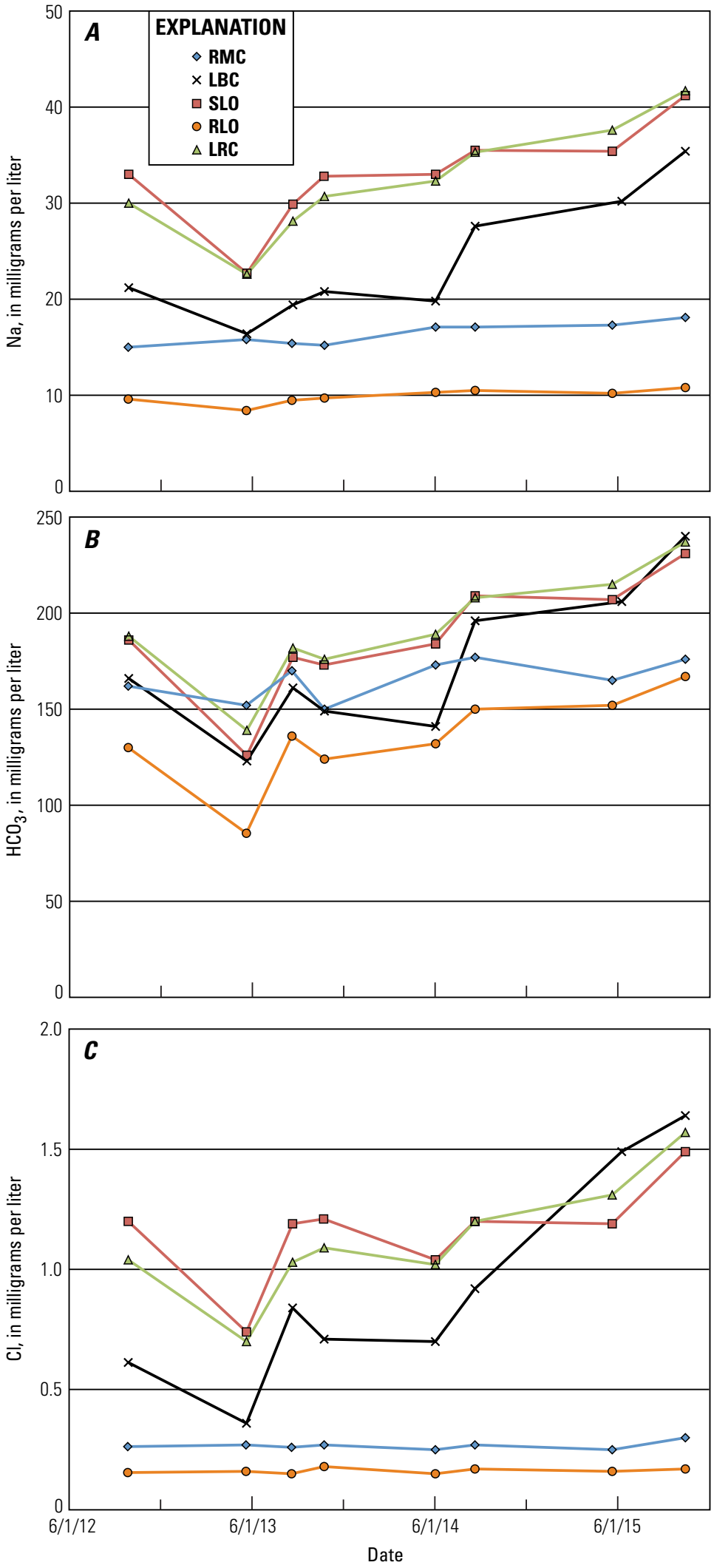

Figure 6. Graphs of concentrations of dissolved species at the five monitoring sites over the course of the study: $(A)$ sodium; $(B)$ alkalinity as $\mathrm{HCO}_{3^{\prime}} ;(C)$ chloride.
The time series of chemical data at the five monitoring sites show some common features (fig. 6). Most sites show a drop in major-ion concentrations in the spring of 2013 followed by generally increasing trends. As will be discussed in more detail later, the drop in spring 2013 is likely a seasonal response to snowmelt; subsequent increases are probably the long-term response to drought. Sites RMC and RLO show less variation than the other sites. Because much of the streamflow at LRC derives from SLO, temporal variations at these two sites show close correspondence.

The other site for which we have a time series is the monument supply well (DPPSW). Results from the downhole CTD probe (fig. $7 A$ ) show a seasonal pattern where water level (expressed as water pressure above the fixed transducer) begins to increase in early spring. The magnitude and seasonality of the pressure rise are comparable to the record from a USGS monitoring well $0.5 \mathrm{~km}$ east of DPPSW (Roeloffs, 2005). Specific conductance drops as pressure rises, reaching a minimum value around the beginning of June, but then increases over a short period to the highest values of the year. Relatively high values generally persist through the summer and most of the fall, when temperature values are also elevated, and short-term variability in all three parameters is most noticeable.

Despite the complexity in the CTD record (fig. 7A), a climate connection is almost certain. The magnitude of the annual variation in water level decreases over the period of record as drought conditions set in. The rise in water level (as pressure) that begins each spring results from pressurization of the aquifer during recharge (Roeloffs, 2005), an effect that is smaller during dry years. The well must tap at least two different groundwater sources to account for the seasonal variability in temperature and specific conductance. After the springtime recharge pulse, summertime pumpage draws in a warmer, more mineralized groundwater component. Pumpage also produces the short-term variability in all parameters during summer and fall, as shown in detail for the month of June 2012 (fig. 7B). During that month, pumpage was significantly elevated on five dates, each of which was temporally linked to declines in water level and increases in specific conductance and temperature.

The CTD probe became unreliable toward the end of its deployment, and data collected after June 6, 2015, was not useable. Several water samples were collected prior to this date (table 2), and some major-ion data are shown in figure $7 C$. The sample in 2013 and the first sample in 2014 were collected toward the end of the springtime low in specific conductance. Other samples were collected after the summertime increase and, as expected, show greater ionic content. Unexpected was the large increase in ionic content in summer 2015 (after removal of the CTD probe). The concentrations of sodium, chloride, and $\mathrm{HCO}_{3}$ are much larger than in previous samples, including a sample collected by 
Figure 7. Graphs of variations over time at the monument supply well (DPPSW). (A) Record from a downhole conductivity-temperature-depth (CTD) probe deployed between August 31, 2009, and June 6, 2015; (B) CTD record for June 2012 with well pumpage data; $(C)$ concentrations of dissolved species in samples collected during our study (2013-15) and in a sample collected 0 ctober 21,2008 by another U.S. Geological Survey group (Shelton and others, 2010).

another USGS group in 2008 when the specific conductance was 101 microsiemens per centimeter $(\mu \mathrm{S} / \mathrm{cm})$ (Shelton and others, 2010). Although specific conductance was not measured in the August 2015 samples, calculated values based on the chemical data in table 2 are near $300 \mu \mathrm{S} / \mathrm{cm}$ - twice as high as any measurement during the $\sim 6$-year CTD record in figure $7 A$. The huge increase in sodium and chloride (fig. 7C) is of particular interest to this study because of the concern about ski-area salt. However, the summer 2015 samples are also highly enriched in $\mathrm{HCO}_{3}$, a minor constituent in ski-area runoff (for example, UDC).

The origins of the sodium and chloride in our samples are investigated in figure 8 . The thermal springs, soda springs, and upper Dry Creek samples are separately designated in these plots, and dashed lines show the trend in which these three water types have evolved from local precipitation, which would plot near the origin. The monument supply well and the San Joaquin River samples are also separately designated; all other springs and spring-fed streams are plotted as "local GW". The line expected from adding salt $(\mathrm{NaCl})$ to pure water (snowmelt) is shown in figure $8 A$ (solid). The UDC samples plot very near the $\mathrm{NaCl}$ line, the thermal springs plot on a much steeper line, and the soda spring samples plot on lines midway between the two. None of the groundwaters collected during this study plot along the UDC trend. The supply-well samples plot on or near the soda spring trend.

Other elements that are not abundant in salt, including bromide, lithium, and boron are shown in figures $8 B-D$. The UDC samples plot near the horizontal axis for all of these elements. For bromide, the thermal line shifts position relative to figure $8 A$, but the supply-well samples continue to plot on or near the soda spring trend. The lithium and boron plots closely resemble the sodium-chloride plot (fig. $8 A$ ).

The lithium and boron plots are shown at expanded scale in figures $8 E-F$ to highlight two remarkable features: (1) the supply-well samples plot on a straight line with minimal scatter, and (2) none of the other groundwaters plot on this line but instead adhere closely to the thermal spring line. If increasing chloride in the supply well were due to addition of salty water from the ski area, the line through the supply-well samples would show more scatter and downward curvature toward the UDC trend. We can conclude that (1) no ski-area salt can be recognized in any

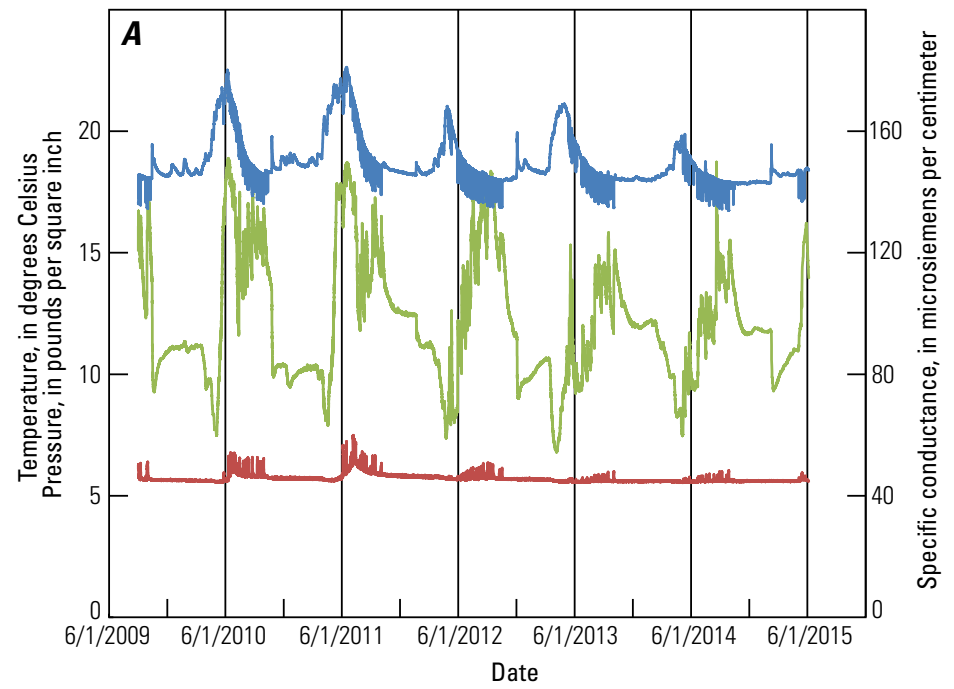

EXPLANATION
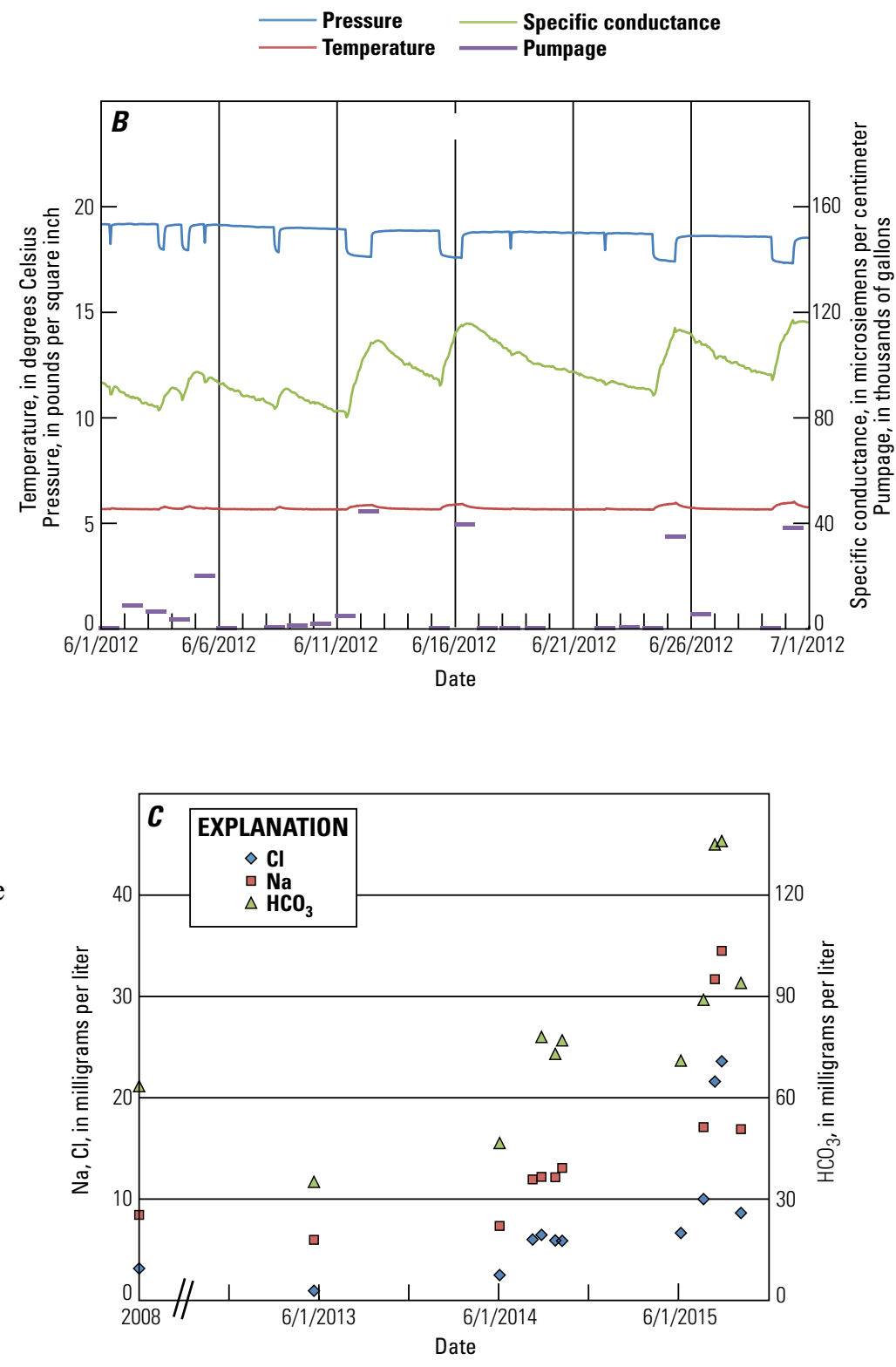

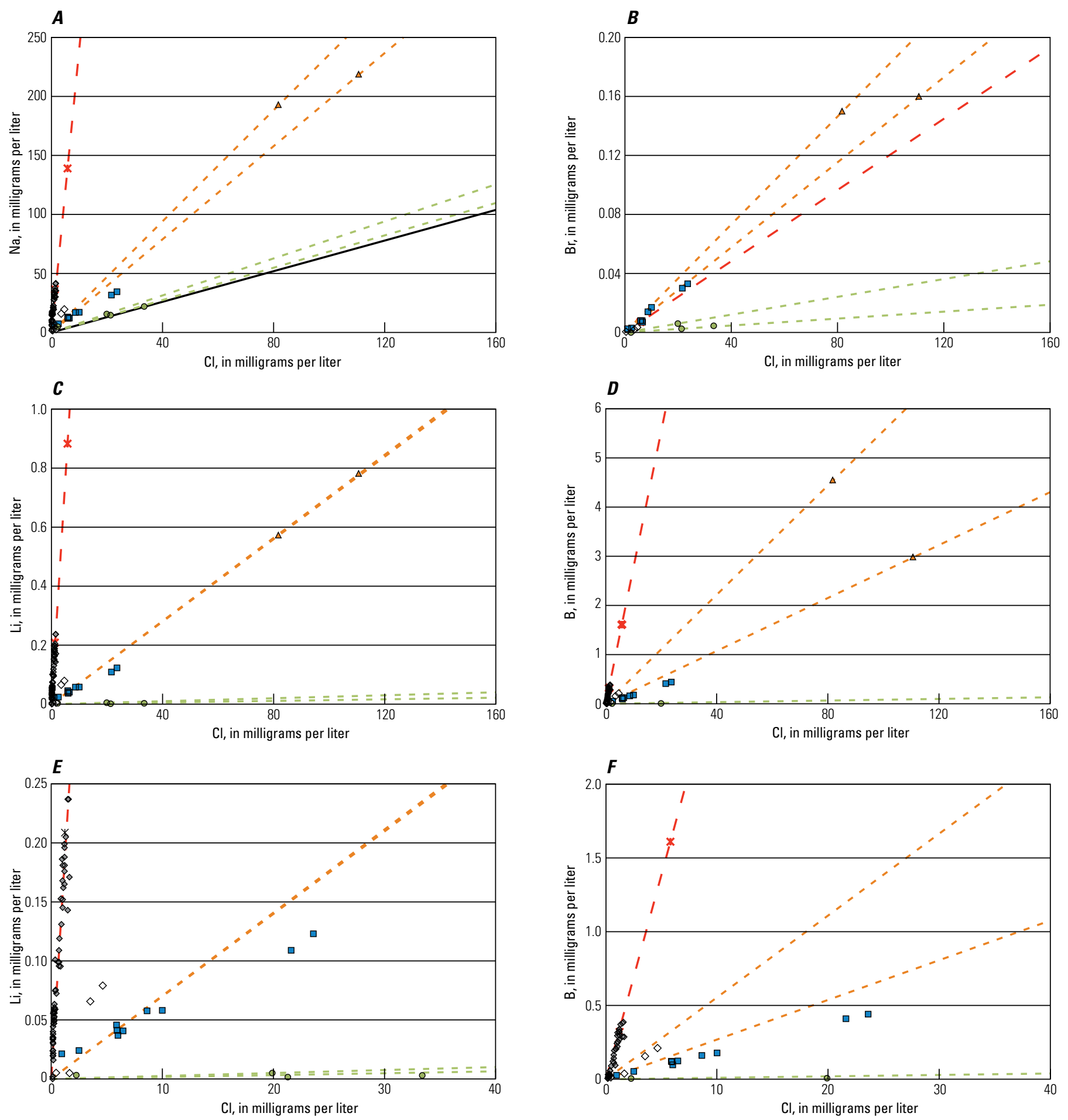

EXPLANATION

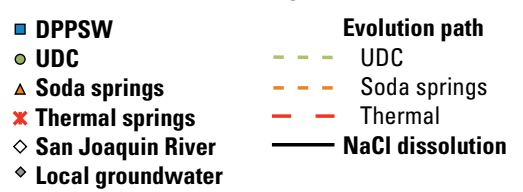

Figure 8. Graphs of the concentrations of several species versus chloride in the monument supply well (DPPSW), upper Dry Creek (UDC), soda springs (DPP Soda and BCSS), thermal springs (RMT and SLS), the San Joaquin River (SJRUP, SJRM, and LSJR), and all other groundwater samples (local groundwater) in table 2 (King Creek and Reds Lake samples omitted). Dashed lines from origin show evolution paths for thermal, soda spring, and upper Dry Creek water types. (A) Sodium, with solid black line for $\mathrm{NaCl}$ dissolution, $(B)$ bromide $(C)$ lithium, $(D)$ boron, $(E)$ lithium at expanded scale, $(F)$ boron at expanded scale. 
of the groundwaters we sampled; (2) most local groundwaters, thermal and non-thermal, are compositionally similar over a large concentration range; (3) the water-supply well taps a component of groundwater that is compositionally distinct from local groundwater and reasonably similar in composition to the two soda springs sampled; and (4) the strength of this soda-spring component varies over time, probably in response to changes in groundwater head and pumpage as indicated by figure 7 . The adherence of most nonthermal groundwaters to the thermal line (for example, in figs. $8 E-F$ ) likely results from similar water-rock interactions, though at lower rates in nonthermal aquifers.

The San Joaquin River samples plot as expected for a mix of dilute water (for example, snowmelt), local groundwater,
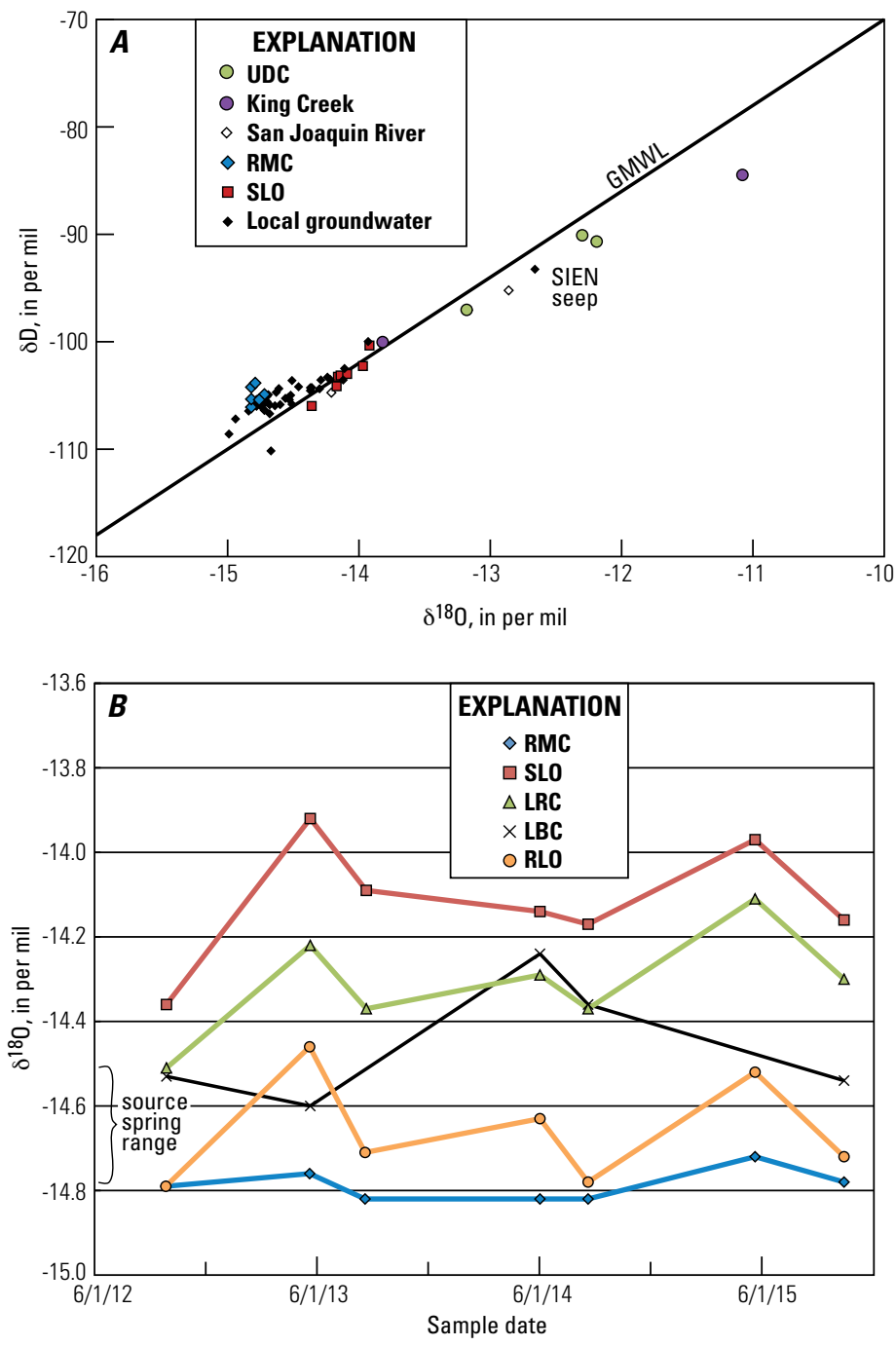

Figure 9. Graphs of stable isotope composition of sampled water. (A) Plot of $\delta \mathrm{D}$ versus $\delta^{18} 0$ with data from monitoring sites RMC and SLO distinguished from all other groundwaters to show the variable effect of evaporation from Sotcher Lake. Samples from upper Dry Creek (UDC), King Creek, and the San Joaquin River represent surface waters. $(B)$ Time series of $\delta^{18} 0$ values at the five monitoring sites compared to the range of values at their source springs (RMCS, LBCU, RLOS, SL1, SL3, SL5, and SL6). GMWL, global meteoric water line. and soda spring water. At high flowrate or at the upstream site, the river is dominated by dilute water and samples plot near the origin. At low flowrate, the downstream sites are more affected by groundwater/soda spring input.

The isotopic compositions of the waters mainly plot in a cluster (fig. $9 \mathrm{~A}$ ) with a few samples shifted toward less negative values, which plot to the right of the global meteoric water line (GMWL) of Craig (1961). This shift shows up mainly in streams that are not directly spring fed where the water has substantial interaction with the atmosphere, such as upper Dry Creek (UDC) and some of the samples from the San Joaquin River and King Creek drainage, and is due to evaporative fractionation. The single groundwater sample that shows a comparably large shift came from the stagnant area of seepage near the SIEN well.

Evaporation from the surface of Sotcher Lake probably also explains why SLO samples shift slightly from the main cluster of points, as compared to the tight grouping for RMC (fig. 9A). The time series of $\delta^{18} \mathrm{O}$ values at the five monitored sites are compared to the range in values obtained at their source springs in figure $9 B$. A small evaporative shift (enrichment) likely affects all of the water isotope values at SLO and is also detectable at the downstream LRC site. Evaporative fractionation may even impact some of the LBC values. The distance between the source springs and the monitoring site LBC is nearly $2 \mathrm{~km}$, so evaporative loss could become significant during the extremely low flow rates observed during our study. However, a clear seasonal pattern is not discernable in our data.

Burak (2010) reported a large seasonal variation ( $\sim 45$ per mil [\%] in $\delta D$ and $\sim 6 \%$ in $\delta^{18} \mathrm{O}$ ) in a few springs on the ridge north of Minaret Summit, just north of our study area. These springs were at high elevations on the ridge where groundwater storage is limited. In this case, seasonal variations in storm tracks, temperature, evaporation, snow ablation, and other factors can show up in the spring discharge, whereas they would be averaged out within a large body of groundwater.

Omitting the San Joaquin River, King Creek, upper Dry Creek, and SIEN seep, our dataset $(n=54)$ yields average values of $-104.9 \%$ for $\delta \mathrm{D}$ and $-14.5 \%$ for $\delta^{18} \mathrm{O}$. Burak (2010) reported averages $\left(\delta D=-106.7 \% ; \delta^{18} \mathrm{O}=-15.1 \%\right.$ ) for 10 spring samples in the Reds Meadow valley collected in 2008 and 2009. Average values $\left(\delta \mathrm{D}=-106.4 \% ; \delta^{18} \mathrm{O}=-14.8 \%\right.$ ) for $\sim 30$ cold spring and well samples collected from all sides of Mammoth Mountain in the late 1990s were reported by the U.S. Geological Survey (2002). The difference over time is near the limits of analytical precision, especially given that the analyses were performed by different labs at different times, and any climate-related trends may be lost in the noise. The lack of clear seasonal, annual, or decadal variation is consistent with a large groundwater body and a residence time of many years. Tritium data collected in the 1990s from a few of the springs was consistent with groundwater residence times of $\sim 10-30$ years (Evans and others, 2002).

Given the topographic relations (fig. 2), Mammoth Mountain is the logical recharge area for these groundwaters and has 
sufficient volume to store a large quantity of groundwater. A more precise recharge location cannot be determined on the basis of $\delta \mathrm{D}$ and $\delta^{18} \mathrm{O}$, in part because no clear relation between altitude and isotopic composition can be identified for this area (Burak, 2010). Thus, water isotopes are not likely to be useful in tracing inter-basinal flow, but regional isotopic patterns may be altered if climate change shifts the main recharge pattern from one that is dominated by spring snowmelt to one dominated by heavy rainstorms.

All groundwater acquires $\mathrm{CO}_{2}$ from biogenic processes (for example, soil respiration) in the subsurface. In volcanic areas, groundwater can also take up magmatic $\mathrm{CO}_{2}$. Mammoth Mountain is a prolific source of $\mathrm{CO}_{2}$ (Farrar and others, 1995), and previous studies (Sorey and others, 1998; Evans and others, 2002) identified a component of magmatic carbon in nearly every groundwater draining the mountain. Many of these springs were highly enriched in magmatic carbon, with $\mathrm{pCO}_{2}$ levels exceeding 0.1 atmosphere and concentrations of dissolved inorganic carbon (DIC), which includes dissolved $\mathrm{CO}_{2}$ and all bicarbonate/ carbonate species, exceeding 10 millimoles per kilogram. Some of the springs sampled in this study, such as RMCS and LBCU, were included in those earlier studies, but springs in the granitic rocks north of Sotcher Lake (fig. 1) were thought to be isolated from Mammoth Mountain and were not sampled.

The carbon isotope composition, specifically the ratios of ${ }^{13} \mathrm{C} /{ }^{12} \mathrm{C}$ and ${ }^{14} \mathrm{C} /{ }^{12} \mathrm{C}$, of the DIC distinguishes magmatic from biogenic carbon. Magmatic carbon at Mammoth Mountain is characterized by a $\delta^{13} \mathrm{C}$ value near $-5 \%$ and a ${ }^{14} \mathrm{C}$ content of 0 in percent modern carbon. Biogenic carbon has a $\delta^{13} \mathrm{C}$ value $<-15 \%$ and contains $>100$ percent modern carbon, and the mixing line between these two carbon sources is well established for local groundwaters (Evans and others, 2002). We did not make any new ${ }^{14} \mathrm{C}$ measurements, but by projecting the new $\delta^{13} \mathrm{C}$-DIC values obtained for five of the springs onto the mixing line of Evans and others (2002; their fig. 5) it is clear that magmatic carbon predominates in all of these waters, including the spring (RLOS) in granitic rocks below Reds Lake (fig. 10).

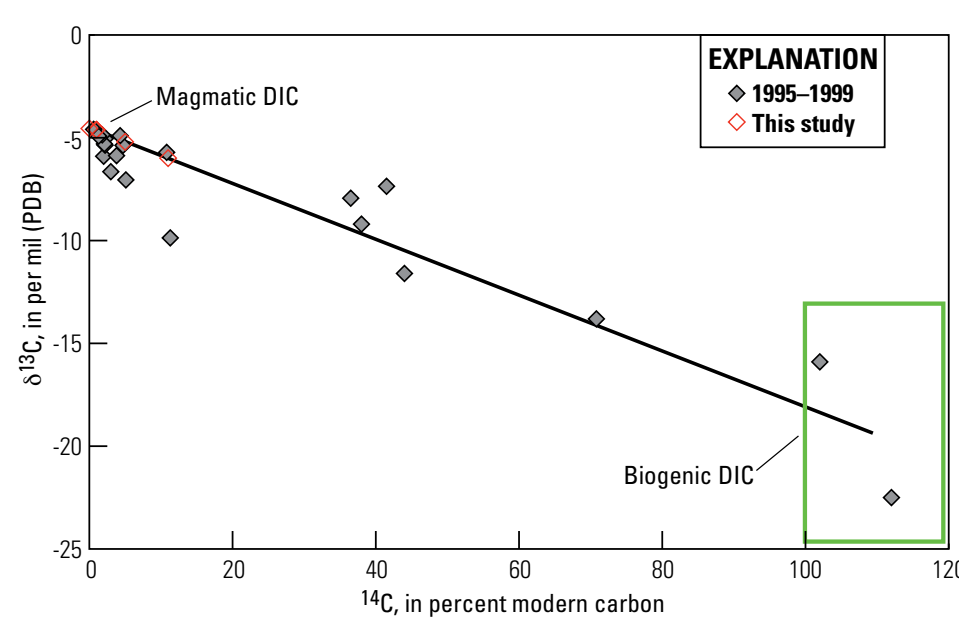

Figure 10. Graph of the isotopic composition of dissolved inorganic carbon $\left(\delta^{13} \mathrm{C}-\mathrm{DIC}\right)$ for five samples obtained in this study, plotted on the biogenic/magmatic mixing line from Evans and others (2002).
Five $\delta^{13} \mathrm{C}$-DIC values, as well as calculated $\mathrm{pCO}_{2}$ and DIC values for the springs sampled in this study (streams are not included as they lose $\mathrm{CO}_{2}$ to the atmosphere), are shown in table 3. Spring RMRS, with a DIC concentration of 0.78 , represents biogenic background, but even springs as DIC-rich as SL6 and the SIEN seep (DIC from 2.96 to 4.12) might contain only biogenic carbon. Spring RLOS contains mostly magmatic carbon based on carbon isotopes, and spring SL1, in the same granitic ridge, appears to be equally enriched in magmatic carbon based on DIC and $\mathrm{pCO}_{2}$. Hildreth and others (2014) point to the contact between the granitic ridge and the volcanic rocks of Mammoth Mountain as the likely conduit for upflow of deep magmatic $\mathrm{CO}_{2}$. Groundwaters draining the granitic ridge would only contain magmatic carbon if their flowpaths crossed this contact. Thus DIC and carbon isotopes, along with majorion chemistry, connect RLOS and SL1 to Mammoth Mountain.

\section{Emerging Contaminants}

Detections of emerging contaminants are listed in table 4 and the complete list of emerging contaminants (EC) analyzed is shown in table 5. Representative detection limits are given, but the analyzing laboratory will report values below these detection limits and those data are associated with qualifying explanatory codes, which are given in table 4 . For our data, the only case of a compound exceeding its normal detection limits is that of caffeine in one of the samples from upper Dry Creek. Low confidence in general can be placed on such low concentration values, and interpretation of the emerging contaminants must account for the fact that some of the detections can be spurious, as is in fact demonstrated by the finding of d-limonene in one of the field blanks. Nevertheless, the compounds detected at the various sites include those expected for the types of visitation activities and likely do provide a meaningful picture of groundwater vulnerability toward contamination.

As anticipated, the largest number of EC compounds by far appeared in the upper Dry Creek samples. Moreover, the same compounds, with one exception, were detected in both samples, and the compounds are those likely to be present at the ski area (table 4). Isophorone is used as a paint additive and wood preservative and could be derived from the many buildings in the main lodge area. Caffeine and skatol are excreted in urine and feces and their presence implies outdoor delivery to the mountain (site UDC is upstream from the treatment plant). Benzophenone could be derived from sunscreens or cosmetics applied on the skin or carried in containers that are dropped on the ski slopes. Methyl salicylate is produced naturally by certain plants, but is probably present here because of its use as a topical analgesic for sore muscles and joints, and its widespread use as flavoring in foods and beverages. Insects are not a wintertime problem on the ski 20 slopes but some sunscreens contain DEET as a repellent. The skiarea parking lot also serves as a staging ground for summertime hikes into the backcountry, where DEET would be heavily used. Triphenyl phosphate is a flame retardant (among other things) and could be leached from outdoor clothing that has been so treated. We emphasize that these scenarios are entirely conjectural. 
Table 3. Dissolved inorganic carbon (DIC) and the Henry's Law pressure of dissolved $\mathrm{CO}_{2}\left(\mathrm{pCO}_{2}\right)$ calculated from field pH and alkalinity. Measured $\delta^{13} \mathrm{C}$ of DIC.

[DIC in millimoles per kilogram of fluid; $\mathrm{pCO}_{2}$ in atmospheres; $\delta^{13} \mathrm{C}$ in per mil (VPDB); --, no data]

\begin{tabular}{|c|c|c|c|c|c|c|}
\hline Site number & Name & Type & Dates & DIC & $\mathrm{pCO}_{2}$ & $\delta^{13} \mathbf{C}$ \\
\hline 8 & SIEN seep & Seep near monitor well & $5 / 22 / 2013$ & 2.96 & 0.061 & -- \\
\hline 12 & RMRS & Spring on road below Minaret Summit & $5 / 22 / 2013$ & 0.78 & 0.004 & -- \\
\hline 13 & DPP Soda & Soda spring at bridge & $8 / 23 / 2013$ & 21.9 & 0.253 & -- \\
\hline 15 & RMT & Reds Meadow Tub (hot spring) & $10 / 14 / 2015$ & 12.1 & 0.156 & -- \\
\hline 16 & RMCS & Headwater spring on Reds Creek & $8 / 21 / 2013$ & 23.7 & 0.349 & -4.61 \\
\hline 19 & SLS & Sotcher Lake warm spring & $8 / 22 / 2013$ & 11.4 & 0.196 & -5.20 \\
\hline 22 & SL1 & Spring in granite above Sotcher Lake & $8 / 22 / 2013$ & 12.1 & 0.169 & -- \\
\hline 24 & SL3 & Spring from landslide above Sotcher Lake & $8 / 22 / 2013$ & 2.92 & 0.027 & -- \\
\hline 25 & SL4 & Seep at trail above Sotcher Lake & $8 / 22 / 2013$ & 1.97 & 0.009 & -- \\
\hline 26 & SL5 & Seep above alder thicket near Sotcher Lake & $8 / 22 / 2013$ & 2.31 & 0.007 & -- \\
\hline 27 & SL6 & Spring on old pack trail near Sotcher Lake & $8 / 22 / 2013$ & 4.12 & 0.044 & -- \\
\hline
\end{tabular}

Table 4. Emerging contaminant detections.

$[\mu \mathrm{g} / \mathrm{l}$, micrograms per liter, --, no code]

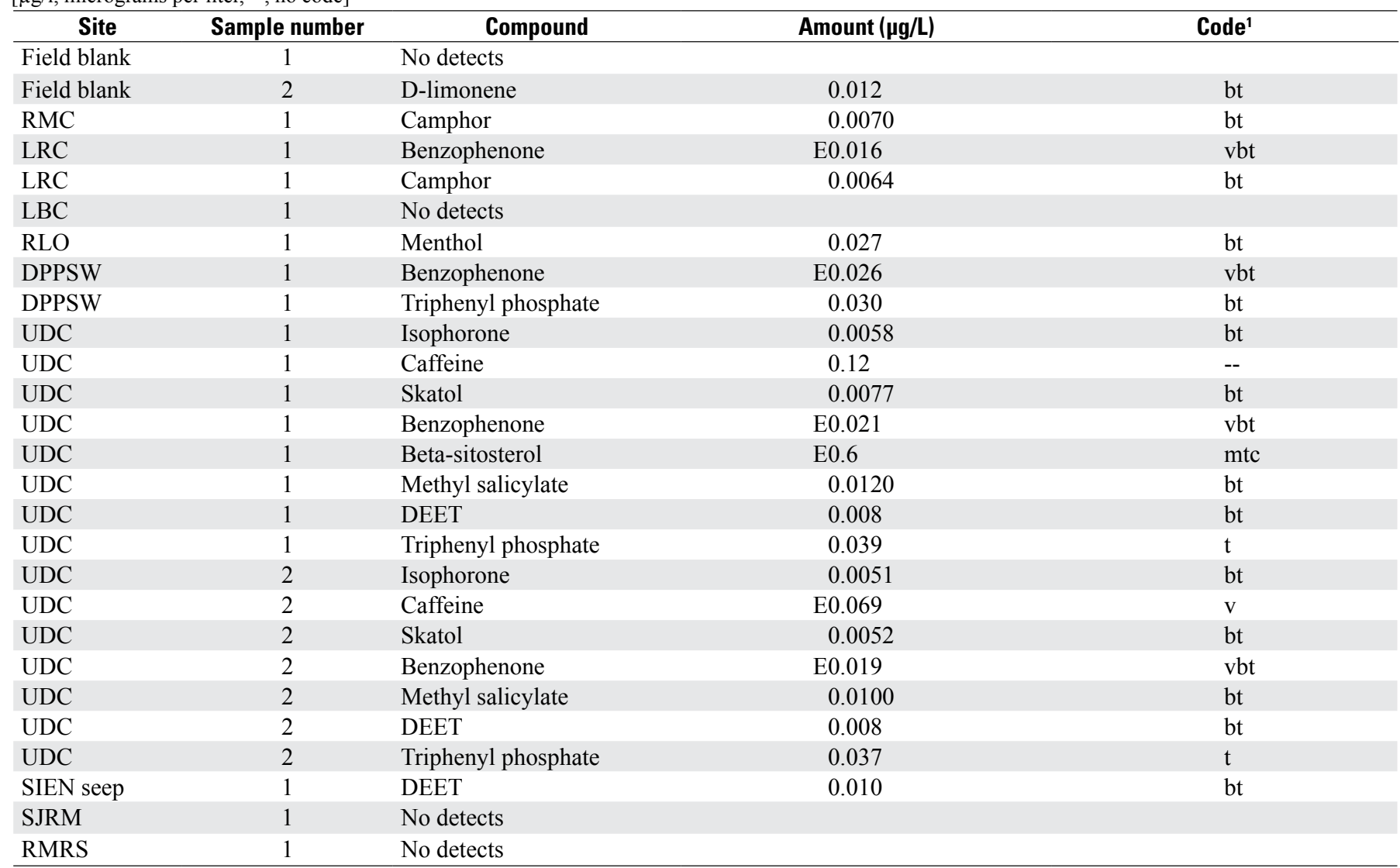

${ }^{\mathrm{b}} \mathrm{b}$, value was extrapolated below the lowest calibration, method, target detection, reporting range, or instrument's linear range; $t$, below the long term mean detection limit; $\mathrm{v}$, analyte detected in laboratory blank, result shows "E"; c, see laboratory comments for this result; m, highly variable compound using this method (flake), questionable precision, and (or) accuracy. 
Table 5. Emerging contaminant compounds and their detection limits, in micrograms per liter.

\begin{tabular}{|c|c|}
\hline Compound & Detection limit \\
\hline Bromacil & $<0.36$ \\
\hline Carbaryl & $<0.16$ \\
\hline Tri(2-butoxyethyl) phosphate & $<0.8$ \\
\hline Triphenyl phosphate & $<0.12$ \\
\hline Triethyl citrate (ethyl citrate) & $<0.16$ \\
\hline Triclosan & $<0.2$ \\
\hline tributyl phosphate & $<0.16$ \\
\hline Tris(dichloroisopropyl) phosphate & $<0.16$ \\
\hline Tri(2-chloroethyl) phosphate & $<0.1$ \\
\hline Beta-stigmastanol & $<2.6$ \\
\hline Para-nonylphenol ( total) (branched) & $<2$ \\
\hline P-cresol & $<0.08$ \\
\hline Diethoxynonylphenol [total) & $<5.0$ \\
\hline N,n-diethyl-meta-toluamide (deet) & $<0.06$ \\
\hline Methyl salicylate & $<0.044$ \\
\hline Menthol & $<0.32$ \\
\hline Isoquinoline & $<0.046$ \\
\hline Isopropylbenzene (cumene) & $<0.3$ \\
\hline Isoborneol & $<0.08$ \\
\hline Indole & $<0.08$ \\
\hline Hexahydrohexamethyl cyclopentabenzopyran (hhcb) & $<0.052$ \\
\hline D-limonene & $<0.08$ \\
\hline Cholesterol & $<2.0$ \\
\hline Carbazole & $<0.03$ \\
\hline Camphor & $<0.044$ \\
\hline Beta-sitosterol & $<4$ \\
\hline Benzophenone & $<0.08$ \\
\hline Anthraquinone & $<0.16$ \\
\hline Acetyl-hexamethyl-tetrahydro-naphthalene (ahtn) & $<0.028$ \\
\hline Acetophenone & $<0.4$ \\
\hline 5-methyl-1h-benzotriazole & $<1.2$ \\
\hline 4-tert-octylphenol & $<0.14$ \\
\hline 4-n-octylphenol & $<0.06$ \\
\hline 4-cumylphenol & $<0.060$ \\
\hline 3-methyl-1h-indole (skatol) & $<0.036$ \\
\hline 3beta-coprostanol & $<1.8$ \\
\hline 2-methylnaphthalene & $<0.036$ \\
\hline 2,6-dimethylnaphthalene & $<0.06$ \\
\hline 1-methylnaphthalene & $<0.022$ \\
\hline Cotinine & $<0.8$ \\
\hline 4-octylphenol monoethoxylate (op1eo) & $<1$ \\
\hline 4-octylphenol diethoxylate (op2eo) & $<1$ \\
\hline Metalaxyl & $<0.12$ \\
\hline Caffeine & $<0.06$ \\
\hline Diazinon & $<0.16$ \\
\hline Metolachlor & $<0.028$ \\
\hline Chlorpyrifos & $<0.16$ \\
\hline 1,4-dichlorobenzene & $<0.04$ \\
\hline
\end{tabular}


Table 5.-Continued

\begin{tabular}{|c|c|}
\hline Compound & Detection limit \\
\hline Tetrachloroethylene & $<0.12$ \\
\hline Pyrene & $<0.042$ \\
\hline Phenol & $<0.16$ \\
\hline Phenanthrene & $<0.016$ \\
\hline Naphthalene & $<0.04$ \\
\hline Isophorone & $<0.032$ \\
\hline Fluoranthene & $<0.024$ \\
\hline Bromoform & $<0.1$ \\
\hline Benz[a]pyrene & $<0.06$ \\
\hline Anthracene & $<0.01$ \\
\hline Prometon & $<0.12$ \\
\hline
\end{tabular}

Few EC compounds were found in sites west of the crest. None were detected in background site RMRS. Site LBC, which mainly drains wilderness area was also contaminant free. Site RLO contains only menthol, probably derived from plants of the mint family that line the streams in this area rather than from human activity. The camphor at site RMC may be naturally sourced (plant-derived) as well, and it persists at the downstream site LRC. The benzophenone at LRC could indicate an impact from human activities in the popular Sotcher Lake and Reds Meadow campground areas, where for example, children wade in the streams during summer. DEET was detected in the SIEN seep near monument headquarters, and this low-flow feature in a marshy area would be a logical place for DEET to accumulate at the land surface. Thus the detections at both LRC and SIEN seep may not reflect contaminant transport by groundwater. Benzophenone and triphenyl phosphate were detected in the DPPSW supply well, where they could indicate impacts from visitation on groundwater at aquifer depths. However, replicate sampling would be needed to verify the presence of these compounds in the well, and if possible, sampling should bypass the installed pump and piping to eliminate potential contamination from these sources.

The San Joaquin River at site SJRM showed no EC detections, and together with the low number of detects at the other sites, indicates that human visitation at current levels does not contribute significant amounts of these compounds to the hydrologic system, a very positive finding on water quality. However, this set of compounds does not appear to provide a useful tool to investigate inter-basinal groundwater flow due to their low concentrations in ski-area runoff.

\section{Streamflow}

Streamflow at each of the five monitoring sites was gaged three times during summer months (2012-14), three times in spring (2013-15), and once in fall (2013) over the course of the study (table 6). The anticipated springtime runoff pulse was only seen in 2013, and apart from that, flow at sites RLO, SLO, and LRC remained fairly constant over the study period while substantially decreasing at the other two sites (fig. 11). Continuous flow in LBC had actually ceased when the site was revisited in August 2015, though flow had resumed at a trickle during another visit in mid-October. During the period of our study, Reds Creek (at LRC) dominated groundwater inflow to the river, and SLO contributed the major part of that flow.

The flow at LRC should be slightly greater than the sum of SLO and RMC because of additional discharge from the hot spring RMT and some other seepage in the Reds Meadow area. Simultaneous gaging at all three monitoring sites should reveal this additional discharge. Although gaging was often spread over days in our study, additional discharge does show up in six out of the seven result groups (table 6), the exception being the May 2013 results, when the high streamflow values made it indiscernible. An overall average value of 4.6 liters per second $(\mathrm{L} / \mathrm{s})$ is calculated for this component.

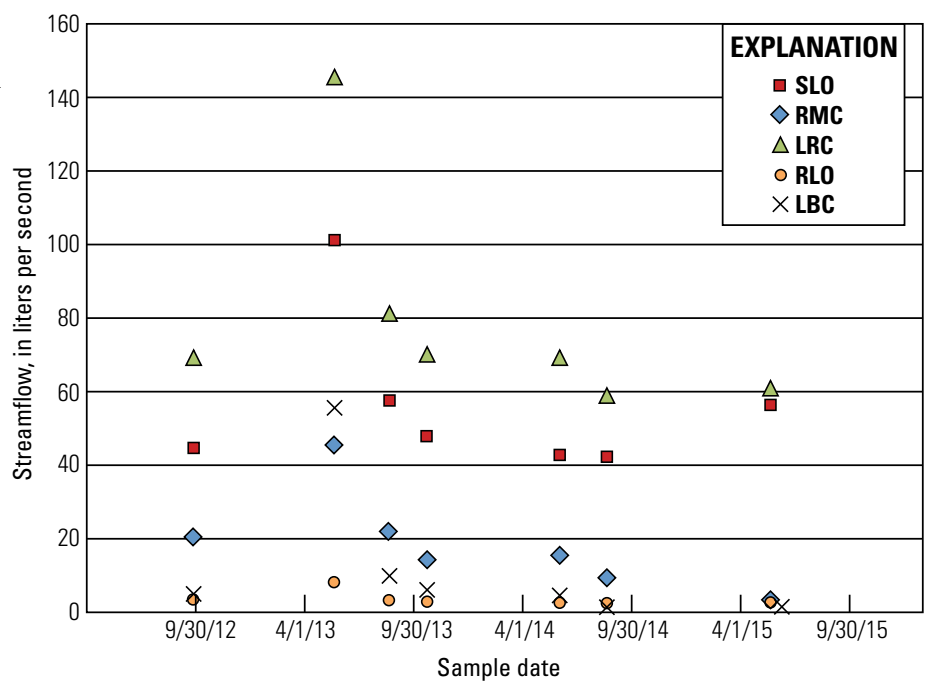

Figure 11. Graph showing gaged streamflows at the five monitoring sites. 
Table 6. Gaged streamflow, in liters per second, at the five monitoring sites.

\begin{tabular}{lcccccccc} 
[--, no data] & & & & & & & & \\
\hline \multicolumn{1}{c}{ Date gaged } & Result group & SLO & RMC & LRC & RLO & LBC & Total & LRC - (RMC + SLO) \\
\hline $9 / 26 / 2012$ & I & -- & 20.5 & -- & 3.5 & -- & -- & -- \\
$9 / 27 / 2012$ & I & 44.7 & -- & 69.3 & -- & 5.0 & 78 & 4.1 \\
$5 / 20 / 2013$ & II & -- & 45.5 & -- & 8.2 & -- & -- & -- \\
$5 / 21 / 2013$ & II & 101.2 & -- & 145.6 & -- & 55.6 & 209 & -1.1 \\
$8 / 19 / 2013$ & III & -- & 22.0 & -- & -- & -- & -- & -- \\
$8 / 20 / 2013$ & III & -- & -- & -- & 3.3 & -- & -- & -- \\
$8 / 21 / 2013$ & III & 57.6 & -- & 81.3 & -- & 9.9 & 95 & 1.7 \\
$10 / 22 / 2013$ & IV & 47.9 & -- & -- & -- & -- & -- & -- \\
$10 / 23 / 2013$ & IV & -- & 14.3 & 70.2 & 2.9 & 6.1 & 79 & 8.0 \\
$6 / 2 / 2014$ & V & 42.8 & 15.5 & 69.3 & 2.6 & 4.6 & 77 & 11.0 \\
$8 / 20 / 2014$ & VI & 42.3 & 9.4 & 59.0 & 2.5 & 1.4 & 63 & 7.3 \\
\hline $5 / 21 / 2015$ & VII & 56.4 & 3.4 & 61.0 & 2.7 & -- & -- & -- \\
$6 / 9 / 2015$ & VII & -- & -- & -- & -- & 1.5 & 65 & 1.2 \\
\hline Average & & 56.1 & 18.7 & 79.4 & 3.7 & 12.0 & 95 & 4.6 \\
\hline
\end{tabular}

${ }^{1} \mathrm{LRC}+\mathrm{RLO}+\mathrm{LBC}$

Comparison of the streamflow values (fig. 11) to the water chemistry (fig. 6) shows that while streamflow more than doubled at every site from fall 2012 to spring 2013 , no site showed a concomitant 50 percent drop in dissolved species, and some sites (especially RMC) showed little change. Thus, only part of the increase in streamflow can be a result of dilution by precipitation or snowmelt. Instead, the recharge pulse likely led to increased discharge of stored groundwater already present in the subsurface, as is commonly assumed in such settings (for example, Tague and Grant, 2004; Burak, 2010). Pressurization of groundwater during recharge was invoked earlier to account for the springtime increase in water level in the supply well DPPSW (fig. $7 A$ ).

Figure 12 shows the flows at three of our monitoring sites compared to that of the San Joaquin River at USGS gage 11224000 , located within the monument. The vertical axes and flow data are scaled such that the May 2013 values for all features plot at nearly the same height. Each year the San Joaquin River flow spikes sharply between the months of April and June as a result of abundant snowmelt in the headwaters area, but then plummets in summer and remains at relatively low levels throughout fall and winter. Sites LRC and RLO, in contrast, maintain a more constant flow through the summer and fall, thanks to the steady discharge of groundwater. The hydrology of Boundary Creek (LBC) is more complex; under dry conditions, spring discharge appears to shift from LBCU to nearby LBCS, which feeds into Crater Creek through two tributaries (LBCS1 and LBCS2).

The importance of groundwater to the San Joaquin River can also be visualized from figure 12. For example, during the spring pulse of May 2013, the flow of LRC was 5.14 cubic feet per second (cfs), just below 2 percent of the river flow ( $295 \mathrm{cfs})$, but by October of that year, the flow of LRC ( $2.48 \mathrm{cfs})$ was 37 percent of the river flow $(6.77 \mathrm{cfs})$. Thus the relative contribution of local groundwater to the water budget of the San Joaquin River varies greatly with the time of year.

The USGS gage on the San Joaquin River was established in late 2009 and has a short period of record. However, there are other gages in this region of the Sierra Nevada with very long records. We selected three sites within $100 \mathrm{~km}$ of the monument where records go back to at least 1940. The sites are located on the Merced River near Yosemite (USGS gage 11266500), the West Walker River near Coleville (USGS gage 10296000), and on Bear Creek near Lake Thomas A. Edison (USGS gage 11230500). The mean annual discharge values by water year for these sites were summed and plotted in figure 13 to provide a long-term picture of wet and dry years in the region (where for example, water year 2011 runs from October 1, 2010, through September 30, 2011). An equally valid picture can be obtained from measurements of water content in the April 1 snowpack. Long-term records of snow water equivalent from two sites (MAM and MN2) near the monument are also shown in figure 13, as well as the shorter record from a site within the monument (DPPC1). The correlation between peaks and valleys in these diverse records is excellent and shows that water year 2011 was wet, water year 2012 was dry, and water year 2013 was near average. Both 2014 and 2015 were among the driest years on record.

Previous gaging near sites LBC and RMC was done by our group in 1997-99 (Evans and others, 2002). Figure 13 shows that these years were wetter than any of the years (2012-15) in the present study, and streamflows were much higher. For example, the flow at RMC on September 8, 1999, was $54 \mathrm{~L} / \mathrm{s}$ and flow at LBC on August 13, 1998, was $282 \mathrm{~L} / \mathrm{s}$. Yet, the water chemistry of the source springs, RMCS and LBCU respectively, were only 

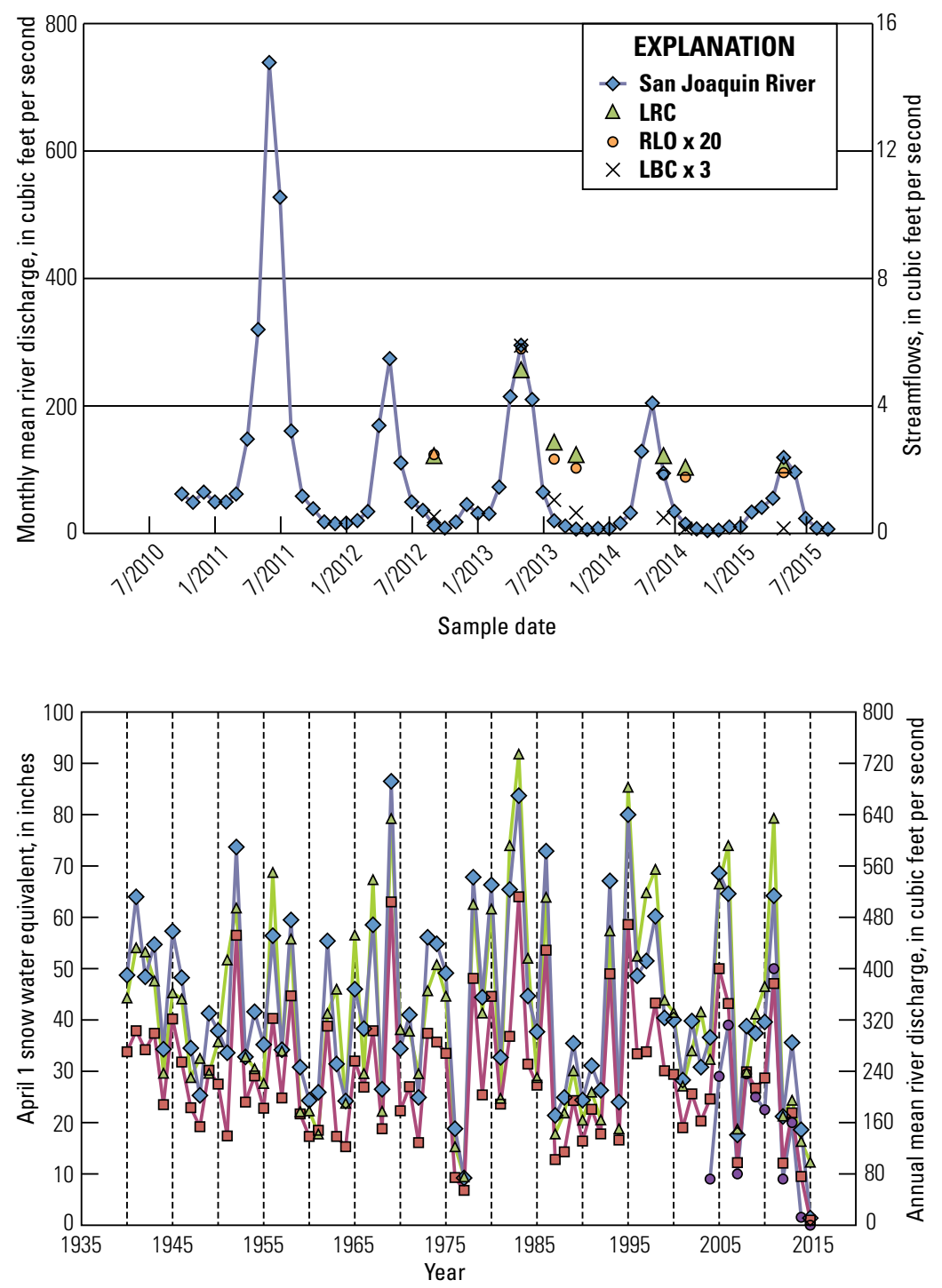

EXPLANATION

$\diamond$ MAM $\triangle$ RIV

$\square$ MN2 ○DPPC1
Figure 12. Graph showing gaged streamflows at sites $\mathrm{LRC}, \mathrm{RLO}$, and $\mathrm{LBC}$, and the monthly mean discharge of the Middle Fork of the San Joaquin River at the monument (USGS gage 11224000) from U.S. Geological Survey (2016a). Note differences in scale and multipliers.
Figure 13. Graph of long-term records of April 1 snow water equivalent (SWE) at Mammoth Pass and Minarets 2 (MAM and MN2) from State of California (2016a,b), and the combined annual mean river discharge by water year at three sites (U.S. Geological Survey gages 11266500, 10296000, 11230500) within 100 kilometers of the monument (RIV) from U.S. Geological Survey $(2016 b, c, d)$. DPPC1 is the complete record of April 1 SWE for a station at the monument from National Weather Service (2016). slightly diluted compared to values we obtained in August 2013 (fig. 5). Water chemistry varies much less than discharge rate, consistent with groundwater residence times much greater than one year.

\section{CTD Probes}

CTD probes were deployed at all five monitoring sites in September 2012, but the SLO and LRC probes failed and were replaced the following summer. The RLO probe recorded data but was impaired by animal activity wherein the communication cable was chewed in half, and the probe position was altered. Destruction of the cable allowed moisture to enter the vent tubing, compromising the depth record. Repositioning of the probe allowed stream gravel to wedge into the conductivity sensor. Thus only the temperature record is considered reliable during the initial period of deployment. The RLO probe was removed in May 2013 and redeployed with new cable in August 2013. The RMC, LBC, and RLO probes all stopped recording after August 2014, whereas the SLO and LRC probes continued recording into 2015. In summary, the records from the various CTD probes are offset in time and shorter than was desired, but at least one complete annual cycle was captured at every site.

\section{Depth}

Stream depth was recorded as a proxy for streamflow. For a stream gaged multiple times over a broad range of flowrates, a rating curve between depth and flowrate can be developed and used to convert a continuous record of depth into a continuous record of flow. Because of the extremely dry conditions in 2014 and 2015, the May 2013 gaging yielded the only high flow 
conditions we were able to capture in this study. Rating curves cannot be adequately constrained in these circumstances, and we must consider depth as only a qualitative indicator of streamflow.

The CTD probes record the pressure of water overlying the probe transducer and convert it into water depth. This depth can also be calculated using the distance to water surface from the reference nail, measured with a steel tape each time the site is visited. The depths obtained from these two methods are in reasonable agreement, apart from the September 2012 readings at RMC (fig. 14).

Given that measurement of the distance from nail to water surface yields a more precise water depth than the probe
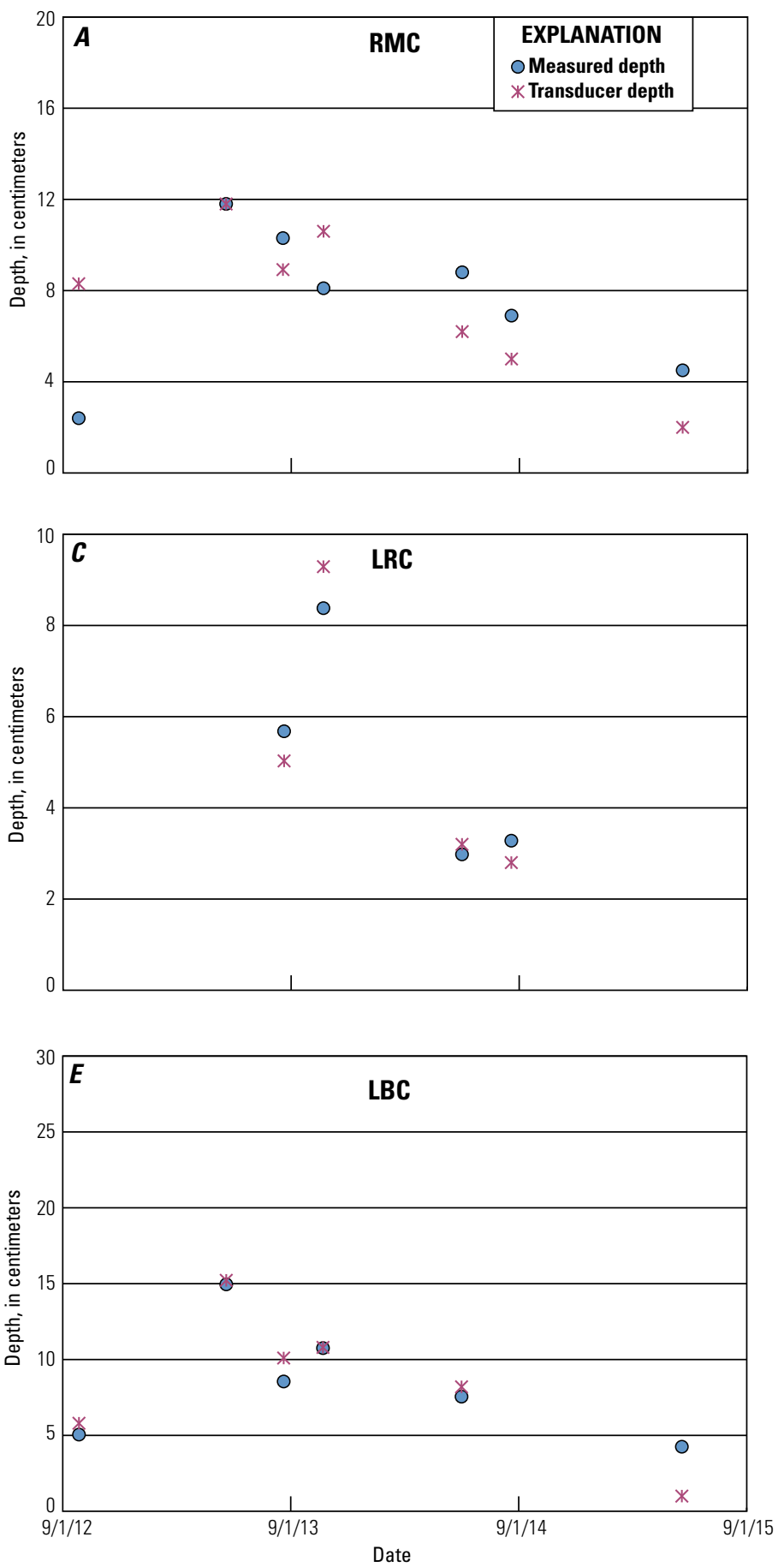

transducer, the measured depths are used to examine the depthstreamflow relation (fig. 15). A qualitative relation can be seen, but with rather striking outliers such as SLO in August 2014 and LRC in October 2013. The probe and measured depths match fairly well on both occasions (fig. 14), and therefore a temporary change in stream morphology is indicated. This can occur, for example, when a log or mass of branches shifts position in the stream near the probe location, creating a change in water depth that is independent of flowrate. In the case of SLO during the summer of 2014, a bank collapse into the stream right at the probe location led to ponding of nearly stagnant water around the sensors. In summary, construction of concrete weirs might be necessary to
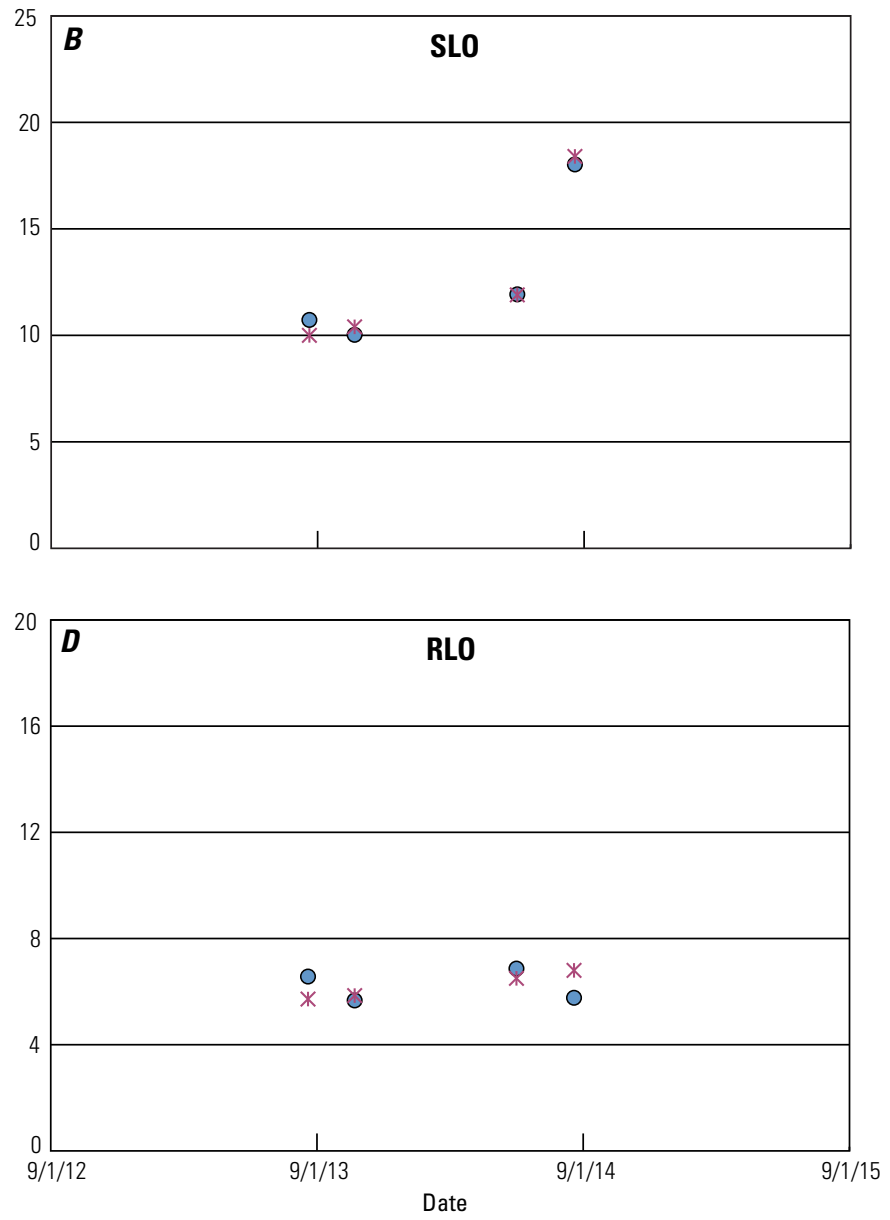

Figure 14. Graphs comparing water depth above the conductivity-temperature-depth probe at each of the five monitoring sites as recorded by the probe transducer and as derived from the measured distance between the water surface and reference point. 
obtain reliable depth-flow relations for these streams, but this was not practical in our low-impact study.

Despite the problems with depth control, some useful information can be extracted from the probe depth records, shown in figure 16. For example, they show that flow in these streams continues throughout the winter months at about the same rates as in summer and fall. Because deep snow can render the sites inaccessible for gaging for nearly half the year, this information is extremely important for constraining annual water budgets. The records generally confirm the limited range in flow rate suggested in figure 11. The spring 2013 runoff pulse appears as a low, broad peak at RMC and a prominent, double peak at LBC. Otherwise,
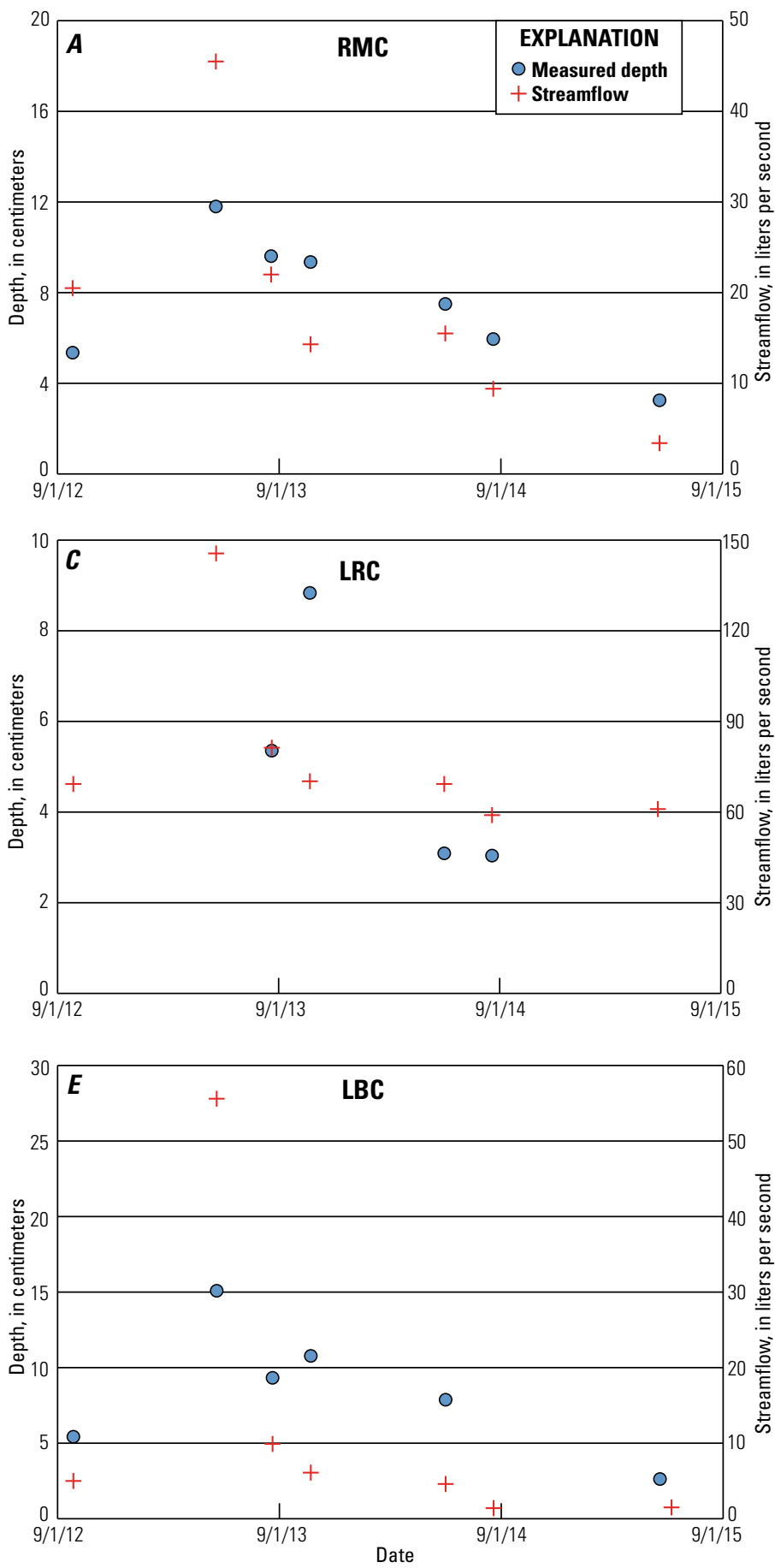

a seasonal pattern is hard to identify. Note that the first part of the depth record at RLO is unreliable due to the damaged vent cable. Also, the apparent offset in depth at SLO beginning in July 2014 is due to the bank collapse mentioned above.

Perhaps the most interesting feature of the depth records (fig. 16) is the short-term variability. Short-lived peaks are an expected response to storms that deliver significant amounts of precipitation, though in this setting, warm spells that result in rapid snowmelt might also be invoked during wintertime. To evaluate the relation between precipitation and streamflow, the depth records in figure 16 are compared to the record of precipitation at the Doe Ridge National Weather and Climate
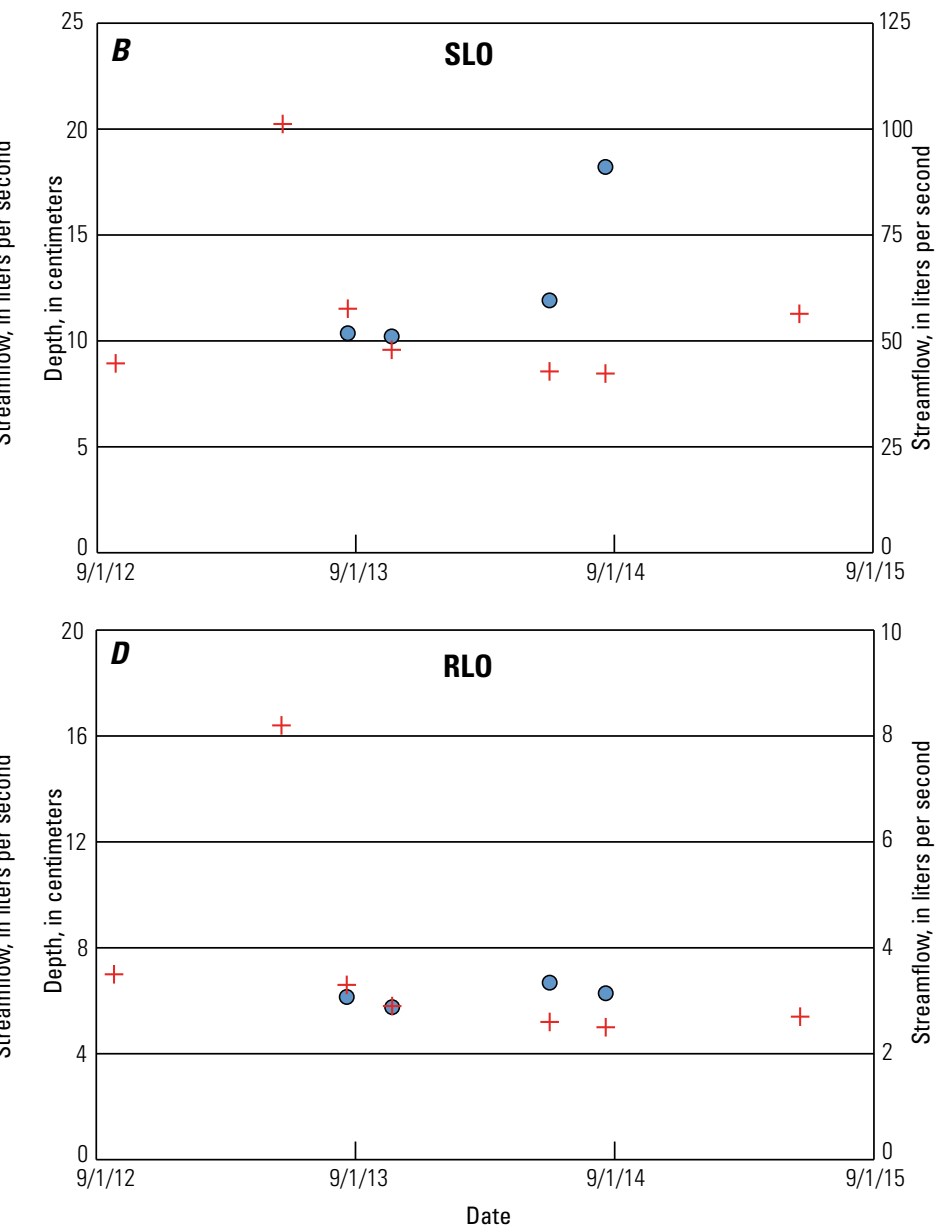

Figure 15. Graphs comparing water depth above the conductivity-temperature-depth probe, as derived from the measured distance between the water surface and reference point, and gaged streamflow at the five monitoring sites. 

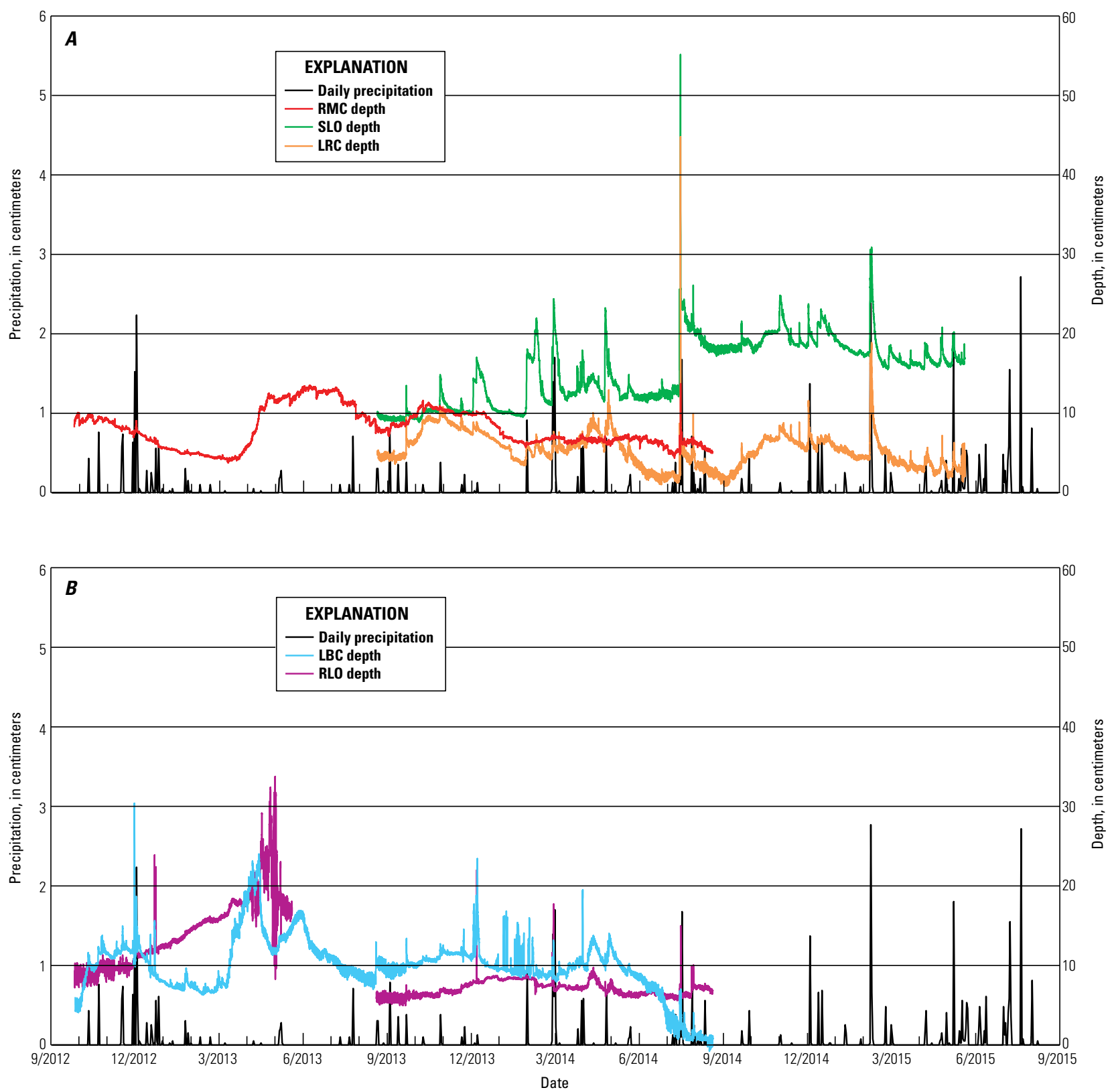

Figure 16. Graphs of stream depths measured by the conductivity-temperature-depth probes and daily precipitation at Doe Ridge (Soil Climate and Analysis Network site 2191) from U.S. Department of Agriculture (2016). See text for notes on probe records.

Center station (U.S. Department of Agriculture, 2016) about $23 \mathrm{~km}$ due east of the monument. Doe Ridge, in the Long Valley caldera east of the Sierran crest, receives significantly less precipitation than the monument. We chose that station in this comparison because it likely records the most significant and widespread storms that affect entire drainage basins, rather than the individual thunderstorms that can be briefly intense but highly localized.

Numerous well-defined peaks in flow at the SLO site (fig. 16A) can all be linked directly to storms, while the RMC site only shows an obvious response to two large storms (in December 2012 and July 2014). That these two nearby streams should respond so differently is fascinating. The general lack of response at RMC can be explained by the fact that Reds Creek above this site drains only pumice-covered volcanic terrain, where rapid infiltration of rainfall prevents direct runoff to the stream. The granitic rocks that make up a substantial part of the Sotcher Lake drainage basin favor more immediate runoff.

The same peaks in the SLO record show up at the downstream site LRC, but are more subdued there, in part because of the added contribution of water from RMC, which lacks most of the peaks. Both RLO and LBC show very sharp spikes (fig. 16B), but these tend to occur mostly in winter and reflect freezing of the water in the pressure transducer. However, all the sites do show at least one true spike-like depth increase due to precipitation, as seen for a large rainfall in July 2014. This major event is the probable cause of the bank failure at SLO. 


\section{Temperature and Specific Conductance}

Temperature and specific conductance are plotted together with depth for all the probes in figure 17. Temperature at all sites shows the expected seasonal pattern of warming in summer and cooling in winter. $\mathrm{LBC}$ and RLO (fig. $17 D, E$ ) reach freezing temperatures in winter, more frequently at $\mathrm{LBC}$ where the probe is far downstream from the spring vents. Freezing temperatures were not reached at RMC, SLO, or LRC (fig. $17 A, B, C$ ) during the course of our study, probably due to higher flow rates and greater proximity of the probes to spring vents that maintain a more constant temperature year-round. All sites show the expected short-term diurnal temperature variation with typically a minimum value in early morning hours and a maximum in the afternoon.
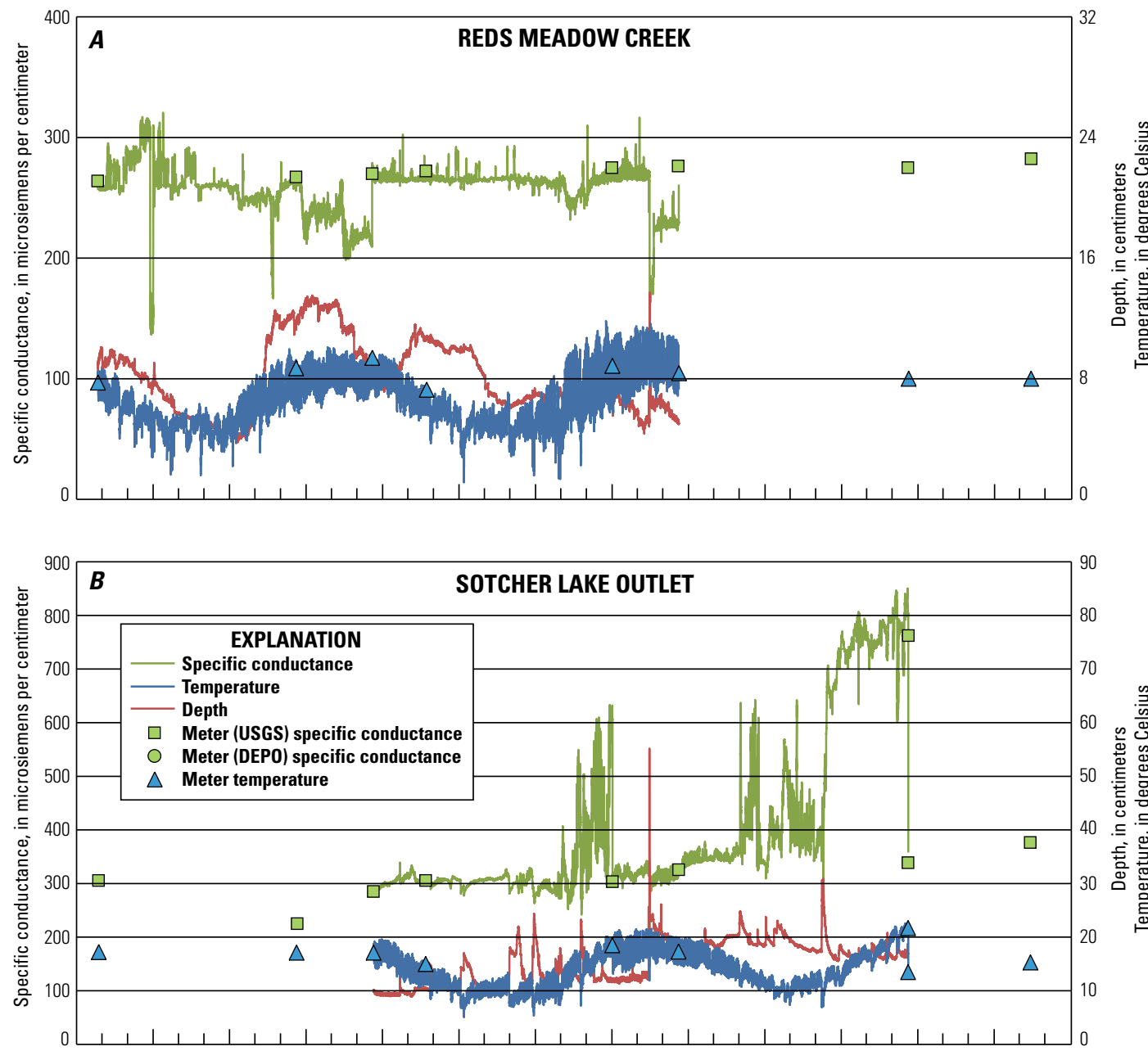

Figure 17. Graphs of temperature and specific conductance for the period from September 1, 2012, to December 1, 2015, from the conductivity-temperaturedepth probes and from hand-held meters used during site visits by U.S. Geological Survey (USGS) and monument (DEPO) staff. Depth records from figure 16 with change in scale. See text for notes on probe records.

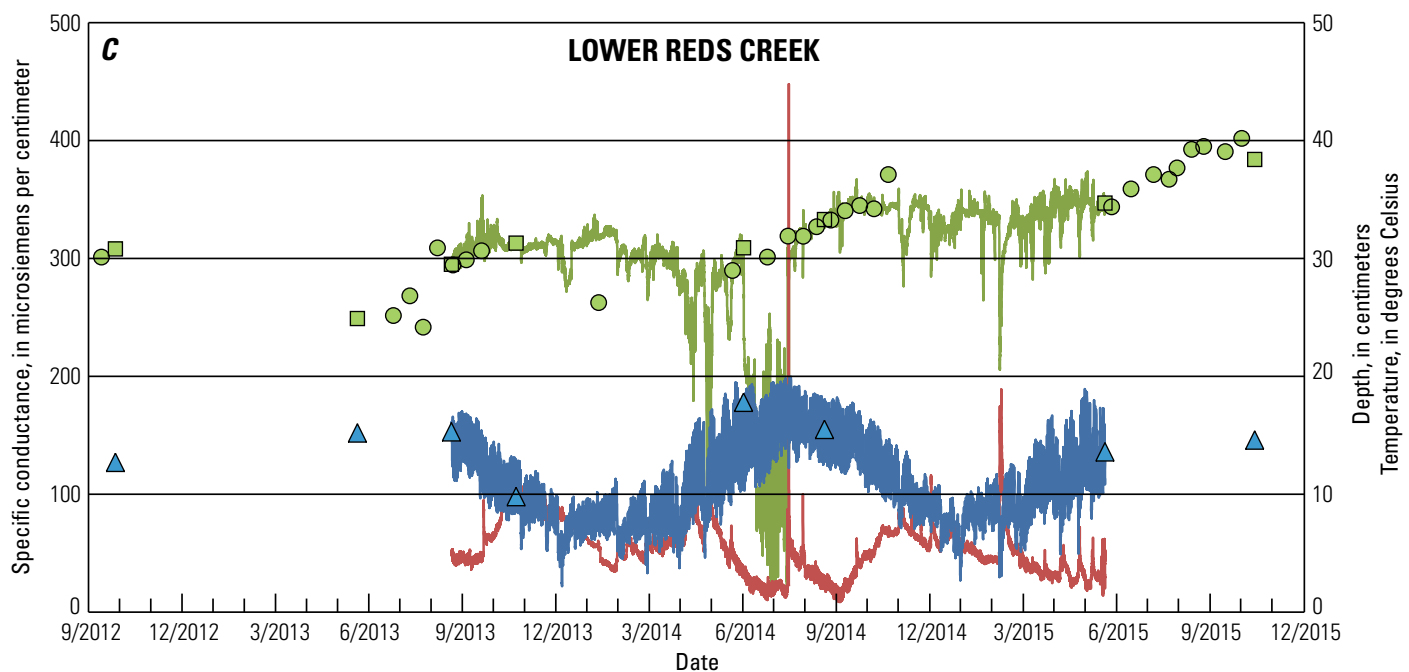



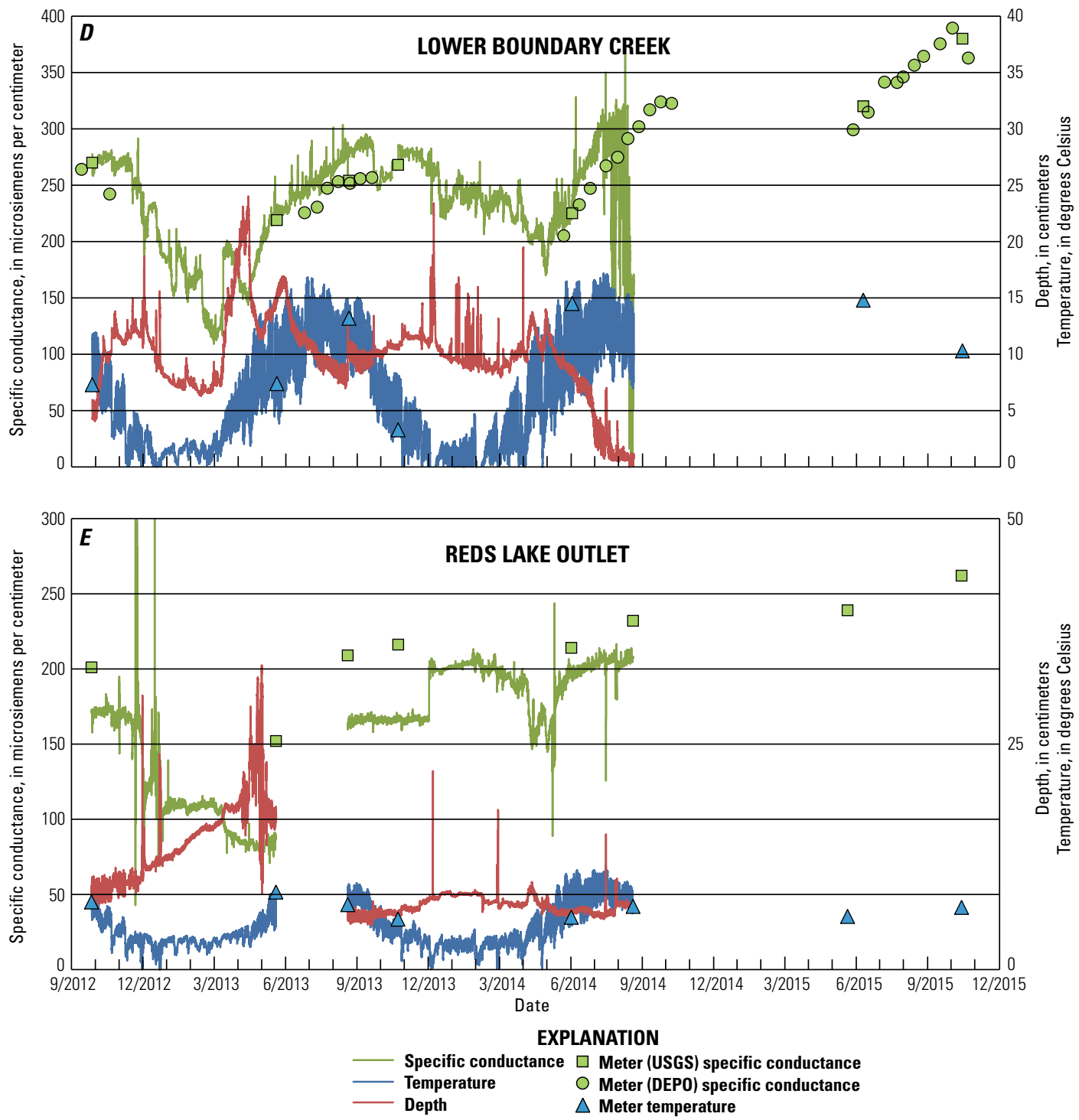

Figure 17.-Continued

Storms can override the diurnal pattern, as exemplified by the expanded record in figure $18 \mathrm{~A}$, or superimpose a period of reduced temperatures lasting several days.

Sites LRC and LBC show a seasonal pattern in specific conductance (fig. 17C,D). These sites also show a long-term increase in specific conductance over the course of the study that is probably drought related. Seasonality and trends are more difficult to discern at the other sites. In general, specific conductance shows less overall variability than either temperature or depth, after problematic values are accounted for.

The specific conductance sensors are located in a narrow slot $(\sim 0.5 \mathrm{~cm})$ near the tip of the CTD probes, and require a continuous flow of stream water through this slot. Unfortunately, the slot forms a natural trap for solid particles carried in the flow, as well as a nucleation site for gas bubbles. Trapped particles and bubbles are apparently dislodged spontaneously, but are the probable cause of many of the sharp positive and negative spikes in all of the specific conductance records (fig. 17). Drift is another problem with these sensors, and this is evaluated by comparison to the readings from calibrated meters taken during sampling visits. Specific conductance is also measured frequently at two of the streams by monument staff during the open season. Overall, the agreement between the meters and the probes was good over the course of the study, but problems that distort the record exist at every site and must be individually explained.

At RMC (fig. 17A), the large negative dip in late 2012 was a sudden drop of $\sim 150 \mu \mathrm{S} / \mathrm{cm}$ between two successive readings 30 minutes apart. The drop occurred on November 27, a full day before the arrival of a series of precipitation events recorded at Doe Ridge. Values increased equally quickly on December 1, while the spike in depth presumably related to the storms did not occur until December 2. Thus the large negative spike in specific 

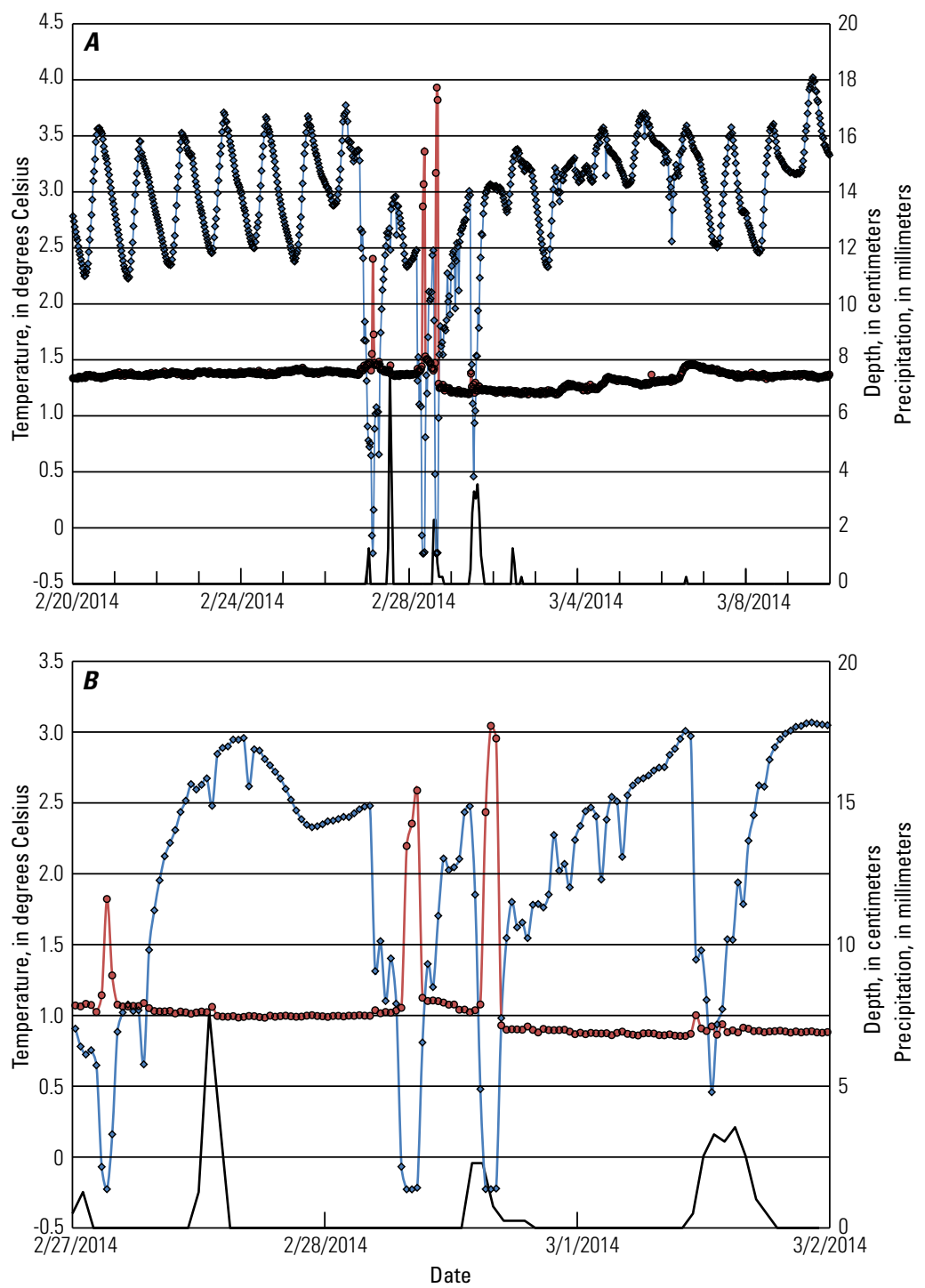

Figure 18. Graphs showing expanded record of temperature and depth from the conductivity-temperature-depth probe at site RLO and hourly precipitation at Doe Ridge from U.S. Department of Agriculture (2016). (A) Disruption of daily temperature cycling during stormy period. (B) Correlation of apparent depth spikes with freezing temperatures.

EXPLANATION

\section{$\because$ Temperature \\ $\multimap$ Depth}

- Precipitation

conductance is likely spurious. Apart from spikes, the field check in May 2013 showed the sensor to have maintained calibration. Beginning shortly after that, values dropped slightly and remained low until the probe was again visited in August 2013. On that visit, the probe was reading $219 \mu \mathrm{S} / \mathrm{cm}$ when first attached to the field reader but then spontaneously jumped to $270 \mu \mathrm{S} / \mathrm{cm}$, in close agreement with the meter. Thus we speculate that the low values of the preceding months were caused by debris in the sensor slot that was dislodged as we accessed the probe.

The large drop in mid-July 2014 corresponds exactly with the jump in depth and both effects correspond to the onset of several days of heavy precipitation. Thus this change in specific conductance could reflect dilution of stream water by direct runoff. However, when the probe was visited a month later, small rocks were found in the sensor slot, and the probe reading was substantially less than the meter value. Removal of these rocks caused the probe reading to jump $\sim 30 \mu \mathrm{S} / \mathrm{cm}$ and approach that of the meter. In summary, the specific conductance of RMC likely remained nearly constant at $\sim 260 \mu \mathrm{S} / \mathrm{cm}$, with perhaps a brief instance of dilution during a large summer storm (fig. 16). The constancy in water chemistry at this site, indicated in figure 6 , apparently held throughout the period of record.

The SLO site was located in a marshy thicket well hidden from public view, but unbeknown to us, at a point where warm, mineralized water seeped into the streambed. Shifting sediment and aquatic vegetation often led to nearly stagnant conditions around this probe. When visited in June 2014, a high specific conductance reading of $600 \mu \mathrm{S} / \mathrm{cm}$ (fig. 17B) was attributed to vegetation that had engulfed the sensor slot because removing the vegetation and sediment and restoring flow to the probe caused readings to drop to a value near that of the calibrated meter $(315 \mu \mathrm{S} / \mathrm{cm})$. The large specific conductance spikes in 
the record during the two months prior to that visit were also attributed to vegetation ingrowth. On a visit the following May (2015), bank collapse and vegetation had again isolated the probe in stagnant water, but on this occasion, a meter reading was taken right next to the probe, confirming the high specific conductance value and demonstrating in-seepage of mineralized water. In hindsight, we now suspect that all specific conductance values exceeding $400 \mu \mathrm{S} / \mathrm{cm}$ are an artifact of seepage, and that the stream itself has a fairly constant value near $300 \pm 100 \mu \mathrm{S} / \mathrm{cm}$. During reliable parts of the record, specific conductance does drop slightly during times of increased flow (depth), particularly noticeable between December 2013 and April 2014.

The specific conductance record at LRC (fig. 17C) had one problem interval in June and July 2014 when the water level dropped so low that the sensor was exposed to air. Apart from that, specific conductance at this site is typically $300 \pm 100 \mu \mathrm{S} / \mathrm{cm}$ yearround. This site does show a clear anticorrelation between spikes in depth and dips in specific conductance, even stronger than its upstream tributary SLO. This strong response could perhaps result from increased surface runoff during storms or rapid snowmelt from the paved Minaret Summit Road, which crosses Reds Creek between the two sites.

The specific conductance record at LBC (fig. 17D) also has a noisy interval at the end of the record when the sensor was exposed to air but appears reliable in other respects. It reveals a strong seasonal pattern in specific conductance, with dilution during winter-spring of both 2013 and 2014. Dilution was greater in 2013, when specific conductance dropped to near $100 \mu \mathrm{S} / \mathrm{cm}$. Otherwise, specific conductance was typically $300 \pm 100 \mu \mathrm{S} / \mathrm{cm}$ year-round. The hand-held meter readings show an overall increase in specific conductance through 2014 and 2015 that matches the chemistry data in figure 6. The same applies to SLO and LRC (figs. 17B,C) and is an effect of prolonged drought.

The relation between specific conductance and depth at LBC (fig. 17D) is complex; for example, specific conductance reaches a minimum prior to the onset of the spring 2013 flow pulse and then increases in unison with that pulse before decreasing again at the height of the pulse. This complex behavior probably results from variations in the proportion of snowmelt to spring discharge into Boundary Creek. The creek normally begins at an area of spring discharge near the crossing of the Pacific Crest Trail, but as discussed earlier, the group of springs split their output between Boundary Creek and the adjacent Crater Creek. We have never observed flow in Boundary Creek above the springs, but creek bed morphology suggests that flow does occur during snowmelt. Thus, periods of snowmelt could lead to increased flow of dilute water as the discharge of spring LBCU varies with changes in the water table. Note that sharp spikes in the depth record reflect freezing water in the probe tip, which also is observed in the record at RLO (fig. 18B).

Even though the conductivity sensor on the RLO probe was calibrated just prior to deployment in September 2012, its initial reading after deployment was $\sim 30 \mu \mathrm{S} / \mathrm{cm}$ lower than the hand-held meter (fig. 17E). Rather than remove the probe and recalibrate the sensor, we decided that a blanket correction of the record could be made at a later date. When the probe had to be pulled in May 2013 due to animal damage, it was taken back to the lab for recalibration. However, right after redeployment in August 2013, it read $\sim 45 \mathrm{~S} / \mathrm{cm}$ lower than the hand-held meter. Then in December 2013, the sensor readings jumped $\sim 30 \mu \mathrm{S} / \mathrm{cm}$ abruptly and were within $25 \mu \mathrm{S} / \mathrm{cm}$ of the hand-held meter on two subsequent visits. Despite these obvious stability problems with the conductivity sensor, the combined data from the probe and hand-held meters suggest that the specific conductance of this stream is typically near $225 \mu \mathrm{S} / \mathrm{cm}$ with a seasonal drop of about $50 \mu \mathrm{S} / \mathrm{cm}$ during spring 2014.

As stated earlier, RLO was chosen as a monitoring site because it is directly downslope from the Reds Lake ski runs and would be the most likely site to show impacts such as salting from ski area operations. As such, the large spikes in the specific conductance record toward the end of 2012 merit extra scrutiny. This part of the record is expanded in figure 19. Precipitation on November 16-17 is closely followed by a small
Figure 19. Graph of expanded record from the conductivity-temperature-depth probe at site RLO and daily precipitation at Doe Ridge showing lack of correlation between conspicuous spikes in specific conductance and precipitation, temperature, or depth.

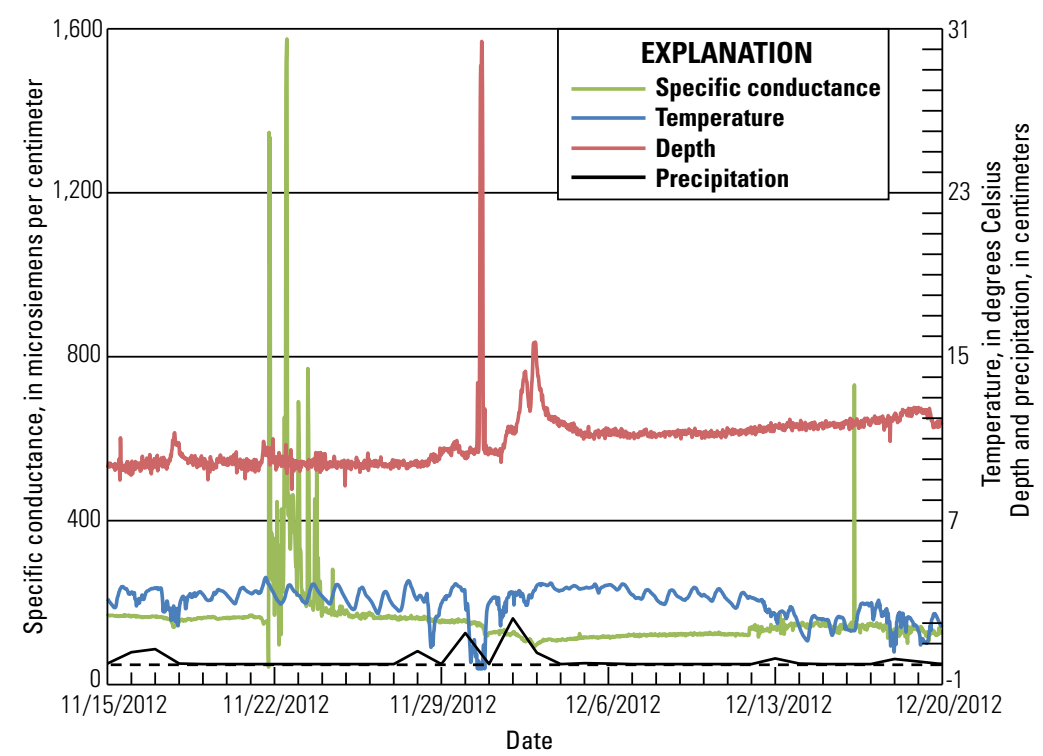


increase in water depth and small decreases in temperature and specific conductance, suggestive of slight dilution of the stream water. Three days later on November 21, the first large spike in specific conductance occurs, but it is not associated with precipitation or any unusual temperature signal, and a brief drop to an unrealistic low value of $43 \mu \mathrm{S} / \mathrm{cm}$ immediately precedes the jump to $1,310 \mu \mathrm{S} / \mathrm{cm}$. A very noisy record with additional spikes persists for the next two days, but then ends with a return to stable values. A drop in temperature to the freezing point results in a spurious depth (pressure) pulse on November 30, during the next period of storms. Specific conductance starts to decline after the sharp depth-spike ends and reaches a minimum value during a several-day period of increased depths that likely correspond to precipitation inputs. The specific conductance record gets slightly noisy again on December 12 , with one more spike on December 16.

If the spikes in specific conductance (fig. 19) were related to wash-in of salt from the ski area, they should correlate with precipitation events. Instead, they seem to occur at random with no discernable connection to precipitation or to other monitored parameters. The depth increases that correspond to storm events (November 17, and December 1-3) are associated with decreases in specific conductance. Thus we conclude that the spikes in specific conductance were due to conductivity sensor instability, possibly exacerbated by the animal damage to the probe cable. No similar spikes were observed after the probe was redeployed in August 2013.

\section{Discussion and Summary}

The goal of this section is to turn the lessons learned from this study into a long-term monitoring plan that can be carried out routinely in the future. Routine sampling of the large number of springs included in this study would be expensive and unnecessary. Many of the springs actually consist of numerous discrete vents that discharge chemically similar groundwater, and the exact location of these vents varies seasonally, mainly tending to shift downslope through summer and fall, and in the case of our study, during drought. Thus, establishing a fixed vent for long-term spring monitoring may be difficult, discharge data from a single vent would be less meaningful than combined discharge of all vents, and the results of this study (fig. 6) along with comparisons to previous studies (figs. 4,5 ) show that spring chemistry is fairly stable over long timeframes.

Continued sampling and gaging at or near the five monitoring sites we used would provide useful information on the aggregate flow of most natural groundwater discharge that ultimately flows into the monument. The LBC site would characterize drainage from unoccupied wilderness, the RLO site would characterize groundwater downslope from part of the ski area, and the LRC site would capture the largest single groundwater inflow to the monument. SLO and RMC could conceivably be omitted because LRC covers their combined flow, but including at least RMC in the monitoring would yield information upstream from thermal water contributions. These factors influence recommendations 1 and 2 below.

Our study covered a period of extreme drought, especially in the final two years (fig. 13). The fact that flows persisted at the monitoring sites, except for brief cessation at LBC in summer 2015 , is a sign of a large and robust groundwater system that will likely provide streamflow and associated habitat through at least similar droughts in the future. However, we were unable to define the seasonal cycle of groundwater discharge during normal-to-wet years, when a limited amount of older data shows that streamflows are much higher. Better constraints on discharge are needed in order to recognize future anomalies that might be human-induced, hence recommendation 3 below.

Groundwaters in the study area were nearly free of a suite of organic compounds commonly related to human activity and known as emerging contaminants (tables 4, 5). The low concentrations, even in the ski-area runoff, limit their use as tracers and therefore repeating this analysis in the near future seems unnecessary. A selection of groundwaters could be analyzed for these organic compounds on an infrequent basis in the future and used to evaluate change, since background information now exists. Otherwise, organic chemistry analyses should focus on specific compounds when there is particular interest, for example, if a study of DEET in amphibians takes place, hence recommendation 4.

Studies in the 1990s (Evans and others, 2002) showed that chloride and $\mathrm{NO}_{3}$ applied to the ski slopes were detectable in the ski-area supply wells at concentrations exceeding 1 milligram per liter $(\mathrm{mg} / \mathrm{L})\left(\mathrm{Cl}_{\max }=17.6 \mathrm{mg} / \mathrm{L}\right.$; $\mathrm{NO}_{3}-\mathrm{N}_{\max }=2.5 \mathrm{mg} / \mathrm{L}$ ). Thus these compounds were easily found in groundwater at the ski area and were certainly detectable $\left(\mathrm{Cl}_{\text {max }}=4.2 \mathrm{mg} / \mathrm{L} ; \mathrm{NO}_{3}-\mathrm{N}_{\max }=1.2 \mathrm{mg} / \mathrm{L}\right)$ in unused supply wells in the Dry Creek drainage, 2-3 km downgradient from the ski area. The ski area stopped applying $\mathrm{NH}_{4} \mathrm{NO}_{3}$ to the runs $\sim 20$ years ago but continues to apply $\mathrm{NaCl}$ at an average rate of 120,000 pounds per year (Clifford Mann, MMSA, oral commun., 2013). Hence the chloride concentrations are high but the $\mathrm{NO}_{3}-\mathrm{N}$ concentrations low in our samples from upper Dry Creek (table 2). The ski area wells were not resampled during this study, but continued infiltration of $\mathrm{NaCl}$ to groundwater at the ski area can be assumed.

The possibility that waters west of the Sierran crest contain ski-area salt can be best evaluated from chemical ratios involving chloride, as noted in recommendation 5 . We used $\mathrm{Cl} /$ $\mathrm{Na}, \mathrm{Cl} / \mathrm{Br}, \mathrm{Cl} / \mathrm{B}$, and $\mathrm{Cl} / \mathrm{Li}$ in figure 8 to show that the chloride in groundwaters in the study area is probably derived from natural sources. Using these chemical ratios, chloride from water interaction with local rocks is distinguishable from soda spring discharge, the strongest natural chloride source in the area. If these ratios were not available, the increase in chloride concentration at some sites as drought conditions persisted (for example, figs. $6 C, 7 C$ ) could be easily misinterpreted.

Although we could not identify ski-area contamination (for example, salt) in groundwaters west of the Sierran crest, the study did reveal a distinct vulnerability. Major-ion chemistry (fig. 3) as well as dissolved inorganic carbon and carbon isotopes (table 3) 
connect some springs such as RLOS and SL1 to recharge on Mammoth Mountain, most likely the Reds Lake area, which is the part of the ski area that is west of the summit. The ski runs in the Reds Lake area are salted minimally and infrequently, most recently in 2010 (Clifford Mann, MMSA, oral commun., 2013). Our sample of Reds Lake from 2013 showed no obvious chloride anomaly (table 2), so the fate of the salt applied in 2010 is unknown. If salting in the Reds Lake area were to be done in the future, the RLO site downslope would be the most likely site to show an effect. Only 120 pounds of salt ( 0.1 percent of the total amount applied annually) would be sufficient to triple the average chloride concentration in RLO for an entire year, assuming an average streamflow of $3.7 \mathrm{~L} / \mathrm{s}$ (table 6) and that the dissolved salt discharged exclusively through this feature. A period of frequent sampling at RLO in the aftermath of salting should reveal any groundwater connectivity to the ski area (see recommendation 6).

The annual variability in the monument supply well, shown in figure $7 A$, and the large increase in dissolved solids late in 2015 (fig. 7C) are intriguing. The hypothesis presented in this report, based on the chemical ratios discussed above, is that the well taps a component of soda water. If true, the visiting public today gets a small taste of the water that the first visitors to the monument might have trekked miles to drink at the bubbling soda springs. However, some anthropogenic chloride contamination could be hidden in the results and this possibility should be investigated further (see recommendation 7).

The potential loss of groundwater to inter-basinal flow eastward is difficult to evaluate. Groundwater withdrawal in the Mammoth Groundwater Basin (by the Mammoth Community Water District) is highly regulated by agreements with the Los Angeles Department of Water and Power. In addition, maintenance of lake levels in the Lakes Basin, located between the monument and the Mammoth Community Water District supply wells, would seem to buffer any impacts on groundwater west of the Sierran crest. The ski area pumps $\sim 5.2 \times 10^{5} \mathrm{~m}^{3}$ of groundwater annually from its wells; about 63 percent of this is used for snowmaking and applied to the ski runs (Breibart and others, 2001). The rest is used for supply, treated on-site, and released into the Dry Creek drainage (below our sampling site UDC). Although some of the water used for snowmaking will recharge the water table, the net removal of groundwater from the area around the main ski lodge is considerable.

We had planned to use our network of CTD probes to check for correspondence between streamflow west of the crest and ski-area pumping schedules, but problems with changing stream morphology and with the probes themselves made this impractical. We suspect that a redeployment of probes would encounter similar problems, even if concrete flumes were installed at the monitoring sites. Assessing the impact of ski-area groundwater withdrawal probably requires that a monitoring well be drilled somewhere west of Minaret Summit (see recommendation 8).

The shallow groundwater near the main ski area is not a shared resource under current conditions. That is, this artificially salted water does not show up in groundwaters west of Minaret Summit, within the limits of our ability to detect it in a comprehensive field survey. However, pumping related drawdown could still affect gradients in adjacent groundwater in such a way as to reduce groundwater availability to the area west of the summit. Alternatively, cessation of pumping at the ski area for any reason; for example, a switch to water imported from distant wells, could allow the salty groundwater to begin draining westward across the divide. Such possibilities, though speculative, should factor into any monitoring plan, which must be modified from time to time to address changing concerns (see recommendation 9).

We conclude by highlighting some intriguing aspects of the regional hydrology where focused research studies and routine monitoring efforts could be mutually beneficial. The singular striking feature of springs draining Mammoth Mountain is that many are unusually rich in $\mathrm{CO}_{2}$ (RMCS is effervescent at the source) for cold, freshwater springs. In wet years like the late 1990s, the springs discharge tens of metric tons per day of $\mathrm{CO}_{2}$, which like the $\mathrm{CO}_{2}$ issuing from the tree-kill areas higher on the mountain, is derived from magma (Evans and others, 2002). During this drought-period study, these same springs discharged just a few metric tons of $\mathrm{CO}_{2}$ per day due to their greatly reduced flowrates. Any relation between annual changes in this dissolved $\mathrm{CO}_{2}$ discharge and the diffuse efflux higher up on the volcano is unconstrained, but could be important to volcano monitoring and to ecological studies in high- $\mathrm{CO}_{2}$ environments (for example, McFarland and others, 2013). To our knowledge, a detailed study of flora and fauna in and around these $\mathrm{CO}_{2}$-rich springs has not been published.

Inter-basinal flow of groundwater has been studied for decades but is often the most difficult term to constrain in basinal water budgets, in part because recharge on both sides of a drainage divide is typically quite similar in chemistry and isotopic composition. In contrast, the heavy application of salt $(\mathrm{NaCl})$ to the snow just east of Minaret Summit creates a contrast in water chemistry across the drainage divide that is extremely unusual, possibly unique, and creates a tremendous opportunity for research on inter-basinal groundwater flow. We did not find evidence for east to west flow in our study, but future research and monitoring should continue to focus on this topic, and ultimately address the question of why it does or does not occur here.

Finally, the area presents a classic study in groundwater management for multiple uses: public supply, recreation, geothermal power production, ecological services, and more. How the various uses are balanced will be key to satisfying the needs of all stakeholders. Groundwater monitoring data, and interpretive studies that use this data, are the tools needed for successful resource management (see recommendation 10).

\section{Recommendations}

(1) Stream gaging and water sampling should be conducted at or in the same reach as the stream monitoring stations used in this report. Two of the sites (RMC and SLO) could be omitted if necessary or visited less frequently. An annual schedule would likely be adequate for long-term monitoring at these sites, but see later recommendations. 
(2) A regular schedule of sampling and discharge measurements at spring vents is probably not necessary. Spring sampling should be considered when unusual changes are observed at any of the monitoring sites (recommendation 1), or when significant events occur in the watershed, for example, a wildfire with borate bombing or greatly increased visitation in an area. Spring sampling would likely occur in association with new hydrologic research projects, especially those involving isotopes.

(3) Although annual stream monitoring might be adequate in the long-term, gaging in spring, summer, and fall is needed to help constrain seasonality in groundwater discharge in wet years. Ideally, this extra monitoring should occur in enough years to define a relation between annual groundwater discharge and precipitation, which could allow one to recognize losses (or gains) in groundwater supply.

(4) Analysis of emerging contaminants could be done at infrequent intervals (decadal?), but a better use of resources would be to focus on organic compounds of specific concern in relation to ongoing research studies or known events of potential groundwater contamination, such as chemical spills.

(5) Water samples collected under this monitoring plan should at least occasionally be analyzed for trace species like boron, lithium, and bromide in addition to chloride. Ratios between chloride and these species provide the most effective way to identify the presence of salt $(\mathrm{NaCl})$ from the ski area. Because of the dilute nature of the waters, analytical precision should be near $0.002 \mathrm{mg} / \mathrm{L}$ for boron, lithium, and bromide, and $0.02 \mathrm{mg} / \mathrm{L}$ for chloride.

(6) An agreement should be reached with the ski area for advance notification of salt use in the Reds Lake area. Water samples should be collected as frequently as possible at RLO for a period of at least six months after salting. These samples could be analyzed for chloride only, but should be analyzed for other species (for example, boron, lithium) if chloride anomalies are found.

(7) The CTD probe in the monument supply well should be kept in good repair, and a complete suite of water samples should be collected at times of high, low, and intermediate specific conductance values and analyzed as described above. Any shift in chemical ratios toward a salt $(\mathrm{NaCl})$ source should be carefully investigated. After a few years of data, sampling frequency could probably be reduced to an annual basis.

(8) Although continuous records of streamflow could reveal impacts of groundwater pumping east of the Sierran crest, such records are probably not obtainable at the required level of precision. A dedicated monitoring well on or west of the Sierran crest would be needed. A monitoring well could perhaps be a point of discussion in any future agreement that involves a major change in groundwater withdrawal or usage.

(9) Groundwater monitoring activities should be reviewed annually to make certain that the results address the concerns of the day, which can change as time goes by. In particular, major changes in development and water usage/ disposal at the ski area could require some change in the type and location of monitoring required.
(10) Hydrologic research in and around the monument should be encouraged as the best way to ensure that monitoring addresses concerns that might be identified and to ensure that monitoring data is put to optimum use. For example, one of the major spring-fed streams in the area (LBC) temporarily went dry during our study. Not surprising perhaps, given the severity of the drought, but the modeling capability to predict such an occurrence, or its ecological consequences are not yet developed.

\section{References Cited}

Bailey, R.A., 1989, Geologic map of Long Valley caldera, MonoInyo craters volcanic chain, and vicinity, eastern California: U.S. Geological Survey Map I-1933, 11 p.

Bergfeld, D., Lewicki, J.L., Evans, W.C., Hunt, A.G., Revesz, K., and Huebner, M., 2013, Geochemical investigation of the hydrothermal system on Akutan Island, Alaska, July 2012: U.S. Geological Survey Scientific Investigations Report 2013-5231, $20 \mathrm{p}$.

Breibart, A.D., Cathcart, R.E., Didriksen, K.A., and Everett, J.L., 2001, Mammoth groundwater extraction-A hydrological analysis of potential recharge to an eastern Sierra watershed: Santa Barbara, University of California, M.S. in Environmental Science and Management Project, 112 p. [Also available at http://www.esm.ucsb.edu/research/2001group_projects/final_ docs/mammoth_final.pdf.]

Buchanan, T.J., and Somers, W.P., 1969, Discharge measurements at gaging stations: U.S. Geological Survey Techniques of Water Resources Investigations, book 3, chap. A8, 65 p.

Burak S., 2010, Geochemical composition of springs and surface water-Devils Postpile National Monument: Report submitted to National Park Service Devils Postpile National Monument, Snow Survey Associates, 15 p.

Cook, A.C., Hainsworth, L.J., Sorey, M.L., Evans, W.C., and Southon, J.R., 2001, Radiocarbon studies of plant leaves and tree rings from Mammoth Mountain, $\mathrm{CA}-\mathrm{A}$ long-term record of magmatic $\mathrm{CO}_{2}$ release: Chemical Geology, v. 177, p. $117-131$.

Craig, H., 1961, Isotopic variations in meteoric waters: Science, v. 133 , p. $1702-1703$.

Eakin, T.E., Price, D., and Harrill, J.R., 1976, Summary appraisals of the nation's ground-water resources-Great Basin Region: U.S. Geological Survey Professional Paper 813-G, 37 p.

Evans, W.C., Sorey, M.L., Cook, A.C., Kennedy, B.M., Shuster, D.L., Colvard, E.L., White, L.D., and Huebner, M.A., 2002, Tracing and quantifying magmatic carbon discharge in cold groundwaters-Lessons learned from Mammoth Mountain, USA: Journal of Volcanology and Geothermal Research, v. 114, p. 291-312. 
Farrar, C.D., Sorey, M.L., Evans, W.C., Howle, J.F., Kerr, B.D., Kennedy, B.M., King, C.-Y., and Southon, J.R., 1995, Forest-killing diffuse $\mathrm{CO}_{2}$ emission at Mammoth Mountain as a sign of magmatic unrest: Nature, v. 376, p. 675-678.

Feth, J.H., Roberson, C.E., and Polzer, W.L., 1964, Sources of mineral constituents in water from granitic rocks, Sierra Nevada, California and Nevada: U.S. Geological Survey Water-Supply Paper 1535-I, 70 p.

Hildreth, W., and Fierstein, J., 2016, Eruptive history of Mammoth Mountain and its mafic periphery, California: U.S. Geological Survey Professional Paper 1812, 128 p., 2 plates, scale 1:24,000. [Also available at http://www.dx.doi. org/10.3133/pp1812.]

Hildreth, W., Fierstein, J., Champion, D., and Calvert, A., 2014, Mammoth Mountain and its mafic periphery-A late Quaternary volcanic field in eastern California: Geosphere, v. 10, p. 1315-1365.

Johnson, C.E., 2013, Nature and history of the Sierra CrestDevils Postpile and the Mammoth Lakes Sierra: National Park Service, Seattle, Wash., 263 p.

Mammoth Community Water District, 2005, Groundwater management plan for the Mammoth Basin Watershed: Mammoth Community Water District, Mammoth Lakes, 45 p. [Also available at http://www.mcwd.dst.ca.us/assets/ final-gwmp.pdf.]

McFarland, J.W., Waldrop, M.P., and Haw, M., 2013, Extreme $\mathrm{CO}_{2}$ disturbance and the resilience of soil microbial communities: Soil Biology and Biochemistry, v. 65, p. 274-286.

National Weather Service, 2016, Station DPPC1 Devils Post Pile raws, in Northern Hemisphere Snow Cover: National Weather Service National Operational Hydrologic Remote Sensing Center database, accessed September 2016, at http://www.nohrsc.noaa.gov.

Nesmith, J., 2015, Wetland monitoring: Project Brief, National Park Service, accessed September 2016, at http://science. nature.nps.gov/im/units/sien/monitor/wetlands.cfm.

Revesz, K., and Coplen T.B., 2008a, Determination of the delta $\left({ }^{2} \mathrm{H} /{ }^{1} \mathrm{H}\right)$ of water-RSIL lab code 1574 , in Revesz, K., and Coplen, T.B., eds., Methods of the Reston Stable Isotope Laboratory, chap. C1: U.S. Geological Survey Techniques and Methods 10-C1, 27 p., accessed September 2016 at $\mathrm{http}: / /$ pubs.water.usgs.gov/tm10C1/.

Revesz, K., and Coplen, T.B., 2008b, Determination of the delta $\left({ }^{18} \mathrm{O} /{ }^{16} \mathrm{O}\right)$ of water-RSIL lab code 489 , in Revesz, K., and Coplen, T.B., eds., Methods of the Reston Stable Isotope Laboratory, chap. C2: U.S. Geological Survey Techniques and Methods 10-C2, 28 p., accessed September 2016, at http://pubs.water.usgs.gov/tm10C2/.
Richard P. Arber and Associates, 2007, Title I preliminary design report-Well relocation project: Draft report to National Park Service, Devils Postpile National Monument, Lakewood, 43 p.

Roeloffs, E., 2005, Coupling of hydrologic effects to borehole strain data: UNAVCO web page, accessed March 2016, at https://www.unavco.org/education/advancing-geodeticskills/short-courses/course-materials/strainmeter/2005strainmeter-course-materials/hydro_coupling.pdf.

Shelton, J.L., Fram, M.S., Munday, C.M., and Belitz, Kenneth, 2010, Groundwater-quality data for the Sierra Nevada study unit, 2008-Results from the California GAMA program: U.S. Geological Survey Data Series 534, 106 p.

Sorey, M.L., Evans, W.C., Kennedy, B.M., Farrar, C.D., Hainsworth, L.J., and Hausback, B., 1998, Carbon dioxide and helium emissions from a reservoir of magmatic gas beneath Mammoth Mountain volcano, California: Journal of Geophysical Research, v. 103, p. 15303-15323.

Sorey, M.L., Suemnicht, G.A., Sturchio, N.C., and Nordquist, G.A., 1991, New evidence on the hydrothermal system in Long Valley caldera, California, from wells, fluid sampling, electrical geophysics, and age determinations of hot-spring deposts: Journal of Volcanology and Geothermal Research, v. 48, p. $229-263$.

State of California, 2016a, Station MAM: State of California Data Exchange Center database, accessed September 2016, at http://cdec.water.ca.gov.

State of California, 2016b, Station MN2: State of California Data Exchange Center database, accessed September 2016, at http://cdec.water.ca.gov.

Tague, C., and Grant, G.E., 2004, A geological framework for interpreting the low flow regimes of Cascade streams, Willamette River Basin, Oregon: Water Resources Research, v. 40, W04303, doi:10.1029/2003WR002629

U.S. Department of Agriculture, 2016, Soil climate and analysis network (SCAN) site 2191: National Water and Climate Center database, accessed September 2016, at https://wcc.sc.egov.usda.gov/nwcc/site?sitenum=2191.

U.S. Geological Survey, 2016a, USGS 11224000 Middle Fork of San Joaquin River near Mammoth Lakes California, in USGS water data for the Nation: U.S. Geological Survey National Water Information System database, accessed September 2016, at http://nwis.waterdata.usgs.gov.

U.S. Geological Survey, 2016b, USGS 11266500 Merced River at Pohono bridge near Yosemite California, in USGS water data for the Nation: U.S. Geological Survey National Water Information System database, accessed September 2016, at http://nwis.waterdata.usgs.gov. 
U.S. Geological Survey, 2016c, USGS 10296000 West Walker River below Lake Walker near Coleville California, in USGS water data for the Nation: U.S. Geological Survey National Water Information System database, accessed September 2016, at http://nwis.waterdata.usgs.gov.

U.S. Geological Survey, 2016d, USGS 11230500 Bear Creek near Lake Thomas A Edison California, in USGS water data for the Nation: U.S. Geological Survey National Water Information System database, accessed September 2016, at http://nwis. waterdata.usgs.gov.

U.S. Geological Survey, 2002, Groundwater and volcanic volatiles: U.S. Geological Survey online database, accessed September 2016, at http://wwwrcamnl.wr.usgs.gov/volcwater/.

Waring, G.A., 1915, Springs of California: U.S. Geological Survey Water-Supply Paper 338, 430 p.
White, A.F., Petersen, M.L., Wollenberg, H., and Flexser, S., 1990, Sources and fractionation processes influencing the isotopic distribution of $\mathrm{H}, \mathrm{O}$, and $\mathrm{C}$, in the Long Valley hydrothermal system, California, U.S.A.: Applied Geochemistry v. 5, p. 571-585.

Wilde, F.D., 2002, National field manual for the collection of water-quality data: U.S. Geological Survey Techniques of Water-Resources Investigations, book 9, chap. A5, 166 p.

Zaugg, S.D., Smith, S.G., Schroeder, M.P., Barber, L.B., and Burkhardt, M.R., 2007, Methods of analysis by the U.S. Geological Survey National Water Quality LaboratoryDetermination of wastewater compounds by polystyrenedivinylbenzene solid-phase extraction and capillarycolumn gas chromatography/mass spectrometry: U.S. Geological Survey Water-Resources Investigations Report 01-4186, $37 \mathrm{p}$. 
